\title{
Essays
}

\section{The Jurisprudence of Justice Byron White}

\begin{abstract}
Allan Ides ${ }^{\dagger}$
\section{INTRODUCTION}

"The respondent in this case killed a 10-year-old child." So states the first sentence of Justice White's dissent in Brewer v. Williams. White approached Brewer from the factual premise that a heinous crime had been committed, while the majority framed the case conceptually, as presenting a "right to counsel" issue. It is this distinction between fact and concept, between underlying transaction and doctrine, that provides critical insight into the jurisprudence of Justice Byron White. White's philosophy cannot be pinned to a single point on any jurisprudential spectrum: conservative to liberal, activist to strict constructionist, interpretivist to noninterpretivist. Nor do such terms as moderate, centrist, or swing vote adequately describe his role on the Supreme Court. Yet, White's jurisprudence is not as unpredictable nor as enigmatic as commentators have suggested. ${ }^{2}$ His critics' frustration may arise
\end{abstract}

$\dagger$ Professor of Law, Washington and Lee University. I would like to express my gratitude to several friends who have patiently listened to my rambling discourses and have read and commented upon various drafts of this Essay. My sincere thanks to Randy Bezanson, Denis Brion, Laura Fitzgerald, Chris May, Brian Murchison, and Lash LaRue. I could not have completed this project without their help. Thanks also to my able research assistants, Lawrence Striley and Eric Reeves, whose efforts and contributions were invaluable. Financial support for this project was provided by a grant from the Frances Lewis Law Center at Washington and Lee University.

1. Brewer v. Williams, 430 U.S. 387, 429 (1977) (White, J., dissenting).

2. See, e.g., Leon Friedman, Byron $R$. White, in 5 THE Justices of THE UNITED STATES SUPREME CourT: THEIR Lives AND MAJOR OPINIONS 345-56 (Leon Friedman ed., 1978); Pierce O'Donnell, Justice Byron R. White: Leading from the Center, 72 A.B.A. J., Special Issue, June 15, at 24 (1986); Monroe E. Price, White: A Justice of Studied Unpredictability, NAT'L L.J., Feb. 18, 1980, at 24; Lance Liebman, Swing 
from an assumption that the formality of law predominates over the transactions that give rise to legal controversies. Not too surprisingly, a jurisprudence that proceeds upon a different assumption may well appear unpredictable or enigmatic within the formal structure. But from a slightly different perspective-from the perspective of legal realism-such a transaction-oriented jurisprudence may appear more coherent.

Of course, I realize that by using the term "legal realism," I am entering a definitional thicket from which there may be no completely satisfactory exit. Exactly who the realists were as well as the specific content of their school of thought remains a matter of continuing debate. ${ }^{3}$ I use the term to capture some of the salient elements that are generally recognized as part of the realist tradition. First, legal doctrine should arise from a clear understanding of how society actually functions. In other words, facts should precede doctrine, and not the converse. Second, lawyers and judges are not necessarily the best fact finders. In fact, to some extent lawyers and judges should be mistrusted as both self-interested and idiosyncratic. Third, and perhaps somewhat incongruously, experts in social science and empirical research will provide the necessary insights into how society functions. And finally, the evolutionary state of society and social institutions requires a government structure that can adapt to changing circumstances. ${ }^{4}$ As such, my definition of legal realism also includes the underlying reformist attitude espoused by some traditional legal realists, of both the Progressive and the New Deal varieties. ${ }^{5}$

Just as the quotation from Brewer v. Williams elevates hard fact over legal concept, this Essay attempts to elevate what Justice White actually did (or attempted to do) over how a more formalist approach might define or categorize the various points in his career. Although the Essay often concentrates on selected doctrinal areas, the purpose is not to catalog doctrine but to examine Justice White's thinking about our political system and the

Man on the Supreme Court, N.Y. TIMES, Oct. 8, 1972, § 6 (Magazine), at 16; Jeffrey Rosen, The Next Justice, NEW REPUBLIC, Apr. 12, 1993, at 21.

3. The supposed realists were never quite sure themselves. WILLIAM TWINING, KARL LLEWELLYN AND THE REALIST MOVEMENT 73-83 (1973); see also JAMES E. HERGET, AMERICAN JURISPRUDENCE, 18701970: A HISTORY 147-227 (1990); John H. Schlegel, American Legal Realism and Empirical Social Science: From the Yale Experience, 28 BUFF. L. REv. 459 (1979). See generally Roscoe Pound, The Scope and Purpose of Sociological Jurisprudence, 24 HARV. L. REV. 591 (1911), 25 HARV. L. REV. 140 (1911); Karl N. Llewellyn, A Realistic Jurisprudence-The Next Step, 30 ColuM. L. REv. 431 (1930); Roscoe Pound, The Call for a Realist Jurisprudence, 44 HARV. L. REV. 697 (1931); Karl N. Llewellyn, Some Realism About Realism-Responding to Dean Pound, 44 HARV. L. REV. 1222 (1931).

4. See Jerome FranK, CoURTS ON TRIAL (1949); HERGET, supra note 3, at 194-227; LALRA Kalman, Legal Realism at Yale, 1927-1960, at 3-44 (1986); KARL N. LlewellyN, The Bramble BuSH (1930); TwINING, supra note 3, at 79 (citing KARL N. LLEWELLYN, JURISPRUDENCE: REALISM IN THEORY AND PRACTICE, $55-57$ (1962)); Harold D. Lasswell \& Myres S. McDougal, Legal Education and Public Policy: Professional Training in the Public Interest, 52 YALE L.J. 203 (1943); John H. Schlegel, American Legal Realism and Empirical Sacial Science: The Singular Case of Underhill Moore, 29 BUFF. L. REV. 195 (1980).

5. See, e.g., FRED RODELL, WOE UNTO YOU, LAWYERS! 249-74 (1939). 
judiciary's role within that system. ${ }^{6}$ This reversal of priorities will provide insight into White's performance as a Justice as well as encourage an appreciation for the perspective from which that performance emanated, a perspective that was influenced by the aura of legal realism and policy science that pervaded Yale Law School while White was a student there.

Speaking more generally, the Essay attempts to show that formal distinctions between doctrines are not, ultimately, distinctions of substance, but of organizational convenience. For example, the separation of powers and the protection of fundamental rights are merely different aspects of the same basic problem regarding the nature and function of our political system. Yet our lack of intellectual dexterity relegates us to draw boundaries that facilitate discussion. At some point, however, the artificiality of these boundaries ought to become apparent. In the end, doctrines are nothing more than different perspectives from which to consider the same basic themes and questions.

\section{Diffusion OF POWER AND the AgENDA OF A MODERN GOVERNMENT}

Our government is formally structured into three branches created by the text of the Constitution and described with neat precision in basic civics books. But as soon as one looks at this system in action, the formal structure begins to dissolve. The constitutional system of checks and balances, including the power of judicial review, ensures that although the branches are technically separate, the separation is never complete. Practicalities of governing further dilute the purity of formal lines. Justice Robert Jackson described this intermingled separation:

The actual art of governing under our Constitution does not and cannot conform to judicial definitions of the power of any of its branches based on isolated clauses or even single Articles torn from context. While the Constitution diffuses power the better to secure liberty, it also contemplates that practice will integrate the dispersed power into a workable government. It enjoins upon its branches separateness but interdependence, autonomy but reciprocity. ${ }^{8}$

6. Given the broad range of issues Justice White considered during his 31 years on the Court, this Essay cannot possibly provide a detailed explication of his judicial career. Thus, many important subjects such as criminal procedure, jurisdiction, and affirmative action will not be discussed. My selection of which cases and topics to discuss was not, however, based on a desire to construct a particular vision of Justice White's jurisprudence, but upon a judgment that the selected materials reflected White's basic judicial attitude. A more detailed and less impressionistic explication of Justice White's judicial career is obviously in order.

7. KALMAN, supra note 4 , at 176-87.

8. Youngstown Sheet \& Tube Co. v. Sawyer, 343 U.S. 579, 635 (1952) (Jackson, J., concurring) (emphasis added). 
This same pragmatic concern-creating a "workable government"preoccupied the legal realists.

Early legal realists sought to discover and understand how law and legal institutions functioned within society. ${ }^{9}$ But functionalism was not merely a tool of discovery; the function of law was thought to be the proper determinant of doctrine. ${ }^{10}$ Justice White's decisions often employed this functionalist analysis. Two of his opinions (both dissents) involving the separation of powers illustrate functionalism and reflect yet another realist theme: the propriety of permitting government to exercise a wide range of flexibility in its quest to resolve complex social problems. While demonstrating both the elegance and utility of functionalism, the opinions expose its shortcomings as well.

Northern Pipeline Construction Co. v. Marathon Pipe Line Co. involved the constitutionality of the Bankruptcy Act of $1978 .{ }^{11}$ At issue was a provision of the Act that authorized the newly created Article I bankruptcy courts to adjudicate state-law claims. Since bankruptcy judges were not Article III judges, the question was whether this conferral of authority violated the principles of Article III.

Justice Brennan's plurality opinion held that Congress may not constitutionally confer Article III adjudicatory power upon institutions that do not meet the conditions set forth in Article III, namely, life tenure and salary independence. Brennan derived his conclusion from the "abstract principle"12 of an independent judiciary. ${ }^{13}$ That is, the opinion first developed the concept, defined independently from the controversy, and then applied the abstraction to the facts. In its conceptual analysis, the plurality did recognize three historical exceptions to the prescriptions of Article III-territorial courts, courts-martial, and courts adjudicating public rights. The bankruptcy courts,

9. KALMAN, supra note 4 , at $3-44$; see also TwINING, supra note 3 , at 74 (providing qualified definition of legal realism and functionalism: "A realist is one who, no matter what his ideological or philosophical views, believes that it is important regularly to focus attention on the law in action at any given time and try to describe as honestly and clearly as possible what is to be seen." (emphasis added)).

10. In three of his nine "points of departure" common to the realist movement, Karl Llewellyn characterized the functionalist component as follows:

(2) The conception of law as a means to social ends and not as an end in itself; so that any part needs constantly to be examined for its purpose, and for its effect, and to be judged in the light of both and of their relation to each other.

(3) The conception of society in flux, and in flux typically faster than the law, so that the probability is always given that any portion of law needs reexamination to determine how far it fits the society it purports to serve. ...

(8) An insistence on evaluation of any part of law in terms of its effects, and an insistence on the worthwhileness of trying to find these effects.

KARL LlEWELLYN, Some Realism About Realism, in JURISPRUDENCE: REALISM IN THEORY AND PRACTICE 42, 55-57 (1962).

11. 458 U.S. 50 (1982).

12. Id. at 113 (White, J., dissenting).

13. Id. at $57-60$. 
however, fell into none of these carefully defined, and hence formal, categories. ${ }^{14}$

Justice White began his dissent with a mock concession: the language of Article III could "easily" be interpreted to require that any court established by Congress meet the conditions set forth in Article III. ${ }^{15}$ Such a reading would be "eminently sensible" and "well founded in both the documentary sources and the political doctrine of separation of powers that stands behind much of our constitutional structure."16 But such an approach would be a "gross oversimplification" and "superficial."17 For White, the Article III doctrine could not be adequately derived from "unsupportable abstractions, divorced from the realities of modern practice." ${ }^{\text {"18 }}$ Rather, a proper analysis must consider the historical and contemporary "functions"19 of the bankruptcy courts and Article III.

White chastised the plurality for its unrealistic appraisal of pre- and postAct bankruptcy courts. While the plurality viewed the conferral of jurisdiction over state-created claims as novel, White argued that bankruptcy court jurisdiction over state-law claims was a common and well-accepted practice prior to the 1978 Act; the new law merely changed the scope of that jurisdiction from in rem to in personam. ${ }^{20} \mathrm{He}$ wrote: "One need not contemplate the intricacies of the separation-of-powers doctrine ... to realize that the majority's position on adjudication of state-law claims is based on an abstract theory that has little to do with the reality of bankruptcy proceedings."21 For White, one must begin with the operational facts. Here that required an appreciation of how bankruptcy courts actually functioned both before and after the adoption of the Act.

On a more general level, White viewed the Court's Article III doctrinal model as out-of-sync with history, precedent, and modern practice. He regarded the three exceptions (territorial courts, courts-martial, and courts adjudicating public rights) not simply as legalistic categories to be construed strictly against a formidable wall of Article III jurisprudence, but as examples of how government structure had developed and changed.

There is no difference in principle between the work that Congress may assign to an Art. I court and that which the Constitution assigns to Art. III courts. Unless we want to overrule a large number of our precedents upholding a variety of Art. I courts-not to speak of those

14. Id. at 64-72. The plurality also held that the bankruptcy courts could not be fairly construed as adjuncts to the district court. Id. at 76-87.

15. Id. at 93 (White, J., dissenting).

16. $I d$.

17. Id.

18. Id. at 101 .

19. Id. at $99,102,103$.

20. Id. at 95-100.

21. Id. at 98 . 
Art. I courts that go by the contemporary name of "administrative agencies"- this conclusion is inevitable. It is too late to go back that far; too late to return to the simplicity of the principle pronounced in Art. III and defended so vigorously and persuasively by Hamilton in The Federalist Nos. 78-82.22

The basic principles of Article III did play a part in his analysis, but only as a relatively fluid check upon the evolving structure of government: "Article III is not to be read out of the Constitution; rather, it should be read as expressing one value that must be balanced against competing constitutional values and legislative responsibilities. This Court retains the final word on how that balance is to be struck."23 In assessing that balance, the key question is the extent to which the legislative scheme undermines the fundamental role of Article III courts, a role which White described as "a firm check on the ability of the political institutions of government to ignore or transgress constitutional limits on their own authority."24 As applied to the Bankruptcy Act, White found neither an aggrandizement of power nor, considering the provision of Article III appellate review, any threat to the essential Article III function of judicial review. ${ }^{25}$

A functional approach to separation of powers is also evident in Justice White's dissent in Immigration and Naturalization Service v. Chadha. ${ }^{26}$ In that case, the Court held that a one-House legislative veto violated the requirements of bicameralism and presentment. The majority undertook a textual exegesis similar to that of the Northern Pipeline plurality. The Court assumed that the words of the Constitution possess a vitality independent of the transaction that gave rise to the controversy. Again, the analysis began with a fully formed doctrine: the language of the Constitution requires that all new laws satisfy the requirements of bicameralism and presentment. Since, in the Court's view, a legislative veto alters the status quo and is therefore tantamount to a new law, a legislative veto must satisfy those requirements. The transaction must conform to the preset doctrine. ${ }^{27}$

22. Id. at 113 .

23. Id.

24. Id. at 115 .

25. Id. at 116-18. In Palmore v. United States, 411 U.S. 389 (1973), Justice White, writing for the Court, upheld the authority of Congress to create legislative courts for the adjudication of crimes committed within the District of Columbia. He observed:

[B]oth Congress and this Court have recognized ... that the requirements of Art. III, which are applicable where laws of national applicability and affairs of national concern are at stake, must in proper circumstances give way to accommodate plenary grants of power to Congress to legislate with respect to specialized areas having particularized needs and warranting distinctive treatment.

Id. at 407-08.

26. 462 U.S. 919, 967-1013 (1983) (White, J., dissenting).

27. See id. at $956-58$. 
According to White, the Chadha Court's exposition of the Bicameralism and Presentment Clauses was both "truismatic" and irrelevant. ${ }^{28}$ The legislative veto, a device unknown to the Framers, was not the same as new legislation and, as a consequence, need not be subjected to the rules specifically designed for such legislation. Rather, the question was whether Congress could reasonably conclude that the legislative veto was an appropriate legislative tool in the modern administrative state. For White, the constitutional analysis began with an understanding of how the underlying transaction-the legislative veto-functioned within the real-world structure of government. The legislative veto

is an important if not indispensable political invention that allows the President and Congress to resolve major constitutional and policy differences, assures the accountability of independent regulatory agencies, and preserves Congress' control over lawmaking. . . .

The history of the legislative veto also makes clear that it has not been a sword with which Congress has struck out to aggrandize itself at the expense of the other branches-the concerns of Madison and Hamilton. Rather, the veto has been a means of defense, a reservation of ultimate authority necessary if Congress is to fulfill its designated role under Art. I as the Nation's lawmaker. ${ }^{29}$

Given the Court's approval of the modern administrative state, White found the Court's disapproval of the legislative veto inexplicable. "If the effective functioning of a complex modern government requires the delegation of vast authority which, by virtue of its breadth, is legislative or 'quasi-legislative' in character, I cannot accept that Art. I . . . should forbid Congress to qualify that grant with a legislative veto." 30

As in Northern Pipeline, White criticized the majority's rigid construction of separation-of-powers doctrine. ${ }^{31}$ White offered instead a more "accomodat[ing] and practical[]" framework:

[T]n determining whether the Act disrupts the proper balance between the coordinate branches, the proper inquiry focuses on the extent to which it prevents the Executive Branch from accomplishing its constitutionally assigned functions. Only where the potential for disruption is present must we then determine whether that impact is justified by an overriding need to promote objectives within the constitutional authority of Congress. ${ }^{32}$

\footnotetext{
28. Id. at $979-80$ (White, J., dissenting).

29. Id. at $972-74$.

30. Id. at 989 (emphasis added); see also id. at 986 ("There is no question but that agency rulemaking is lawmaking in any functional or realistic sense of the word.") (emphasis added).

31. Id. at $998-1000$.

32. Id. at 1000 (quoting Nixon v. Admin'r of Gen. Servs., 433 U.S. 425,443 (1977)).
} 
According to White, nothing in the circumstances of Chadha-the exercise of a legislative veto in the context of a suspension of deportation-suggested any diminution of the executive's ability to carry out any constitutionally mandated function. ${ }^{33}$ As a consequence, the legislative veto was constitutional.

Despite the intellectual appeal of White's Chadha dissent, there is a nagging sense that something is not quite right. White's appraisal of legislative vetoes was itself somewhat formalistic, resting more on a theoretical, rather than an empirical, application of the functional technique; the opinion assumed that legislative vetoes operate both to assist the administrative state and to protect the values inherent in the separation of powers. In particular, White assumed that legislative vetoes actually operate to control administrative discretion. ${ }^{34}$ Moreover, confronting the facts of Chadha, White ignored the somewhat seedy operation of legislative vetoes in the context of deportation, while Chief Justice Burger recognized those facts. ${ }^{35}$ A closer look at legislative vetoes in action, including a more exacting examination of the facts before the Court, may have led to a slightly different "functional" appraisal. ${ }^{36}$ Perhaps White's faith in the administrative state deterred him from taking functionalism to its next logical step.

Overall, the Northern Pipeline and Chadha dissents present a general picture of White's attitude toward the separation of powers. ${ }^{37}$ Quite clearly, Justice White did not view the political structure as static or completely bound by constitutional text. ${ }^{38}$ The government model described and defended by the Framers did not, in White's view, fully capture all possibilities of legitimate government; rather the Framer's model demonstrated how certain principles functioned in eighteenth-century government. Those principles remain the foundation of modern constitutional law. But today's political structure does not and need not conform to any precise formulation beyond the preservation of those core principles. As such, White's approach to separation of powers

33. Id.

34. Indeed, his treatment of this point was relegated to a footnote that recognized the existence of a substantial debate on the issue. See id. at 976 n.12.

35. Id. at $923-28$.

36. For a functional analysis of legislative vetoes, see Brian C. Murchison, The Concept of Independence in Public Law, 41 EMORY L.J. 961, 1005-08 (1992) and Peter C. Strauss, Was There a Baby in the Bathwater? A Comment on the Supreme Court's Legislative Veto Decision, 1983 DUKE L.J. 789, 804-12.

37. See also Metropolitan Wash. Airports Auth. v. Citizens for the Abatement of Aircraft Noise, 111 S. Ct. 2298, 2317 n.3 (1991) (White, J., dissenting) (noting "hollow ring" of claim to legislative tyranny when one considers actual allocations of authority between Congress and Executive); Bowsher v. Synar, 478 U.S. 714, 759-76 (1986) (White, J., dissenting) (challenging Court's "formalistic" rejection of Balanced Budget and Emergency Deficit Control Act of 1985); Palmore v. United States, 411 U.S. 389 (1973) (White, J.) (upholding authority of Congress to create legislative courts for adjudication of crimes committed within District of Columbia).

38. See, e.g., Northern Pipeline, 458 U.S. at 94 (White, J., dissenting) ("Whether fortunate or unfortunate, at this point in the history of constitutional law [the scope of Art. III limits] can no longer be answered by looking only to the constitutional text."). 
conforms with the legal realist tenet that law ought to reflect the reality of changing social conditions.

Within this evolving structure, the judiciary's role should be one of studied deference. The underlying assumptions are that each political branch is in the best position to protect its own prerogatives, and that this internal tension will protect the liberty of the people. The judicial role is not, however, completely passive. In White's view, the Court retains "the final word" on the constitutionality of any political adjustment of the separation of powers. ${ }^{39}$ In rendering its decision, the Court should examine the extent to which the legislative scheme undermines or accommodates the separation-of-powers values at stake; any perceived burdens upon the separation of powers should be balanced against the values Congress hopes to promote. ${ }^{40}$ In practice, this means a functional approach. In Northern Pipeline, for example, White's willingness to uphold the congressional scheme was based upon "ample provision . . . for appellate review by Art. III courts."41 As such, "the critical function of judicial review" had not been displaced by the Article I bankruptcy courts. ${ }^{42}$ Similarly, in Chadha White stated, "I do not suggest that all legislative vetoes are necessarily consistent with separation-of-powers principles. A legislative check on an inherently executive function, for example, that of initiating prosecutions, poses an entirely different question." ${ }^{43}$ These limits demonstrate how core separation-of-powers principles require that certain functions remain in the designated branch. ${ }^{44}$

This notion of fluid separation has a certain, elegant attraction, ${ }^{45}$ for surely any account of separation of powers ought to consider the manner in

39. 458 U.S. at 113 (White, J., dissenting).

40. Id. at 115 .

41. Id. at 116 .

42. Id. (emphasis added).

43. Chadha, 462 U.S. at 1002 (White, J., dissenting). But see Morrison v. Olson, 487 U.S. 654 (1988) (White joins majority opinion upholding independent counsel provisions of Ethics in Government Act of 1978).

44. Justice White applied this functional analysis in Buckley v. Valeo, 424 U.S. 1, 257 (1976) (White, J., concurring in part and dissenting in part). In Buckley, unlike in Northern Pipeline and Chadha, the functional analysis demonstrated that the legislative scheme was unconstitutional because it undermined core separation-of-powers values. In Buckley, which involved a multifaceted challenge to the Federal Election Campaign Act Amendments of 1974, White agreed with the Court's conclusion that the selection process for the Federal Election Commission violated the Appointments Clause. Under the Amendments, FEC members were not appointed pursuant to the Appointments Clause; yet in Justice White's reckoning the members of the FEC were "officers of the United States" within the meaning of that clause-their duties and functions included a vast array of enforcement activities. Although White considered the law's purposes important, he was unwilling to sanction any exceptions to the strictures of the Appointments Clause. White believed that the executive's appointment power was of critical importance to the separation of powers. Id. at 271-75. The Buckley opinion, like the dissents in Northern Pipeline and Chadha, recognized the legitimacy of the administrative state and accepted the changing face of the separation of powers, but deemed the structural imperatives of the Appointments Clause too critical to ignore. See also Bowsher v. Synar, 478 U.S. 714, 765 (1986) (White, J., dissenting) (accepting proposition that Congress may not reserve executive role for itself or its agents).

45. Even the Framers, who were at least in part pragmatists, did not envision anything like a strict separation of powers. THE Federalist No. 51 (James Madison). 
which government actually operates. However, any attempt to make constitutional doctrine fit a judge's perception of functional reality encounters several problems. Applying functionalism, the tripartite model can be excessively fractionalized, with power dispersed in peculiar and even counterintuitive ways. For example, a legislative veto over agency rulemaking inverts the constitutionally established lawmaking responsibilities where Congress initiates new laws and the executive acts as a check. Similarly, Article I judges deciding Article III matters can be seen as dispersing Article III authority, or as preserving core Article III functions by retaining appellate review. Thus relying on functionalism to determine when a constitutional value or principle is threatened may lead to varying conclusions and, potentially, to a pattern of seemingly incoherent results. One needs faith in the competing institutions of government and in the self-restraint imposed out of fear of judicial intervention to subscribe to this evolutionary conception of the separation of powers. Of course, if one accepts that constitutional change occurs when new social phenomena make dogma obsolete, then regardless of trepidation, judges must make this leap of faith as an unavoidable acknowledgement of how governments actually operate. Certainly, this was Justice White's view.

Justice White's functional analysis descends directly from the functionalism promoted by the first generation of legal realists. ${ }^{46}$ For both White and the early realists, the perceived manner in which the law operated was of critical importance. To this end, facts, and not concepts, were of the essence. The law should be constructed around the relevant facts; the reality behind the law ought to be the reality of the law. However, as the brief critique of Chadha suggests, the choice of which facts comprise reality is of no minor significance. The choice of facts may be less an objective measure of reality than a value judgment about the proper result.

Of course, the realists' attraction to functionalism represented more than a fascination with technique; realists viewed functionalism as an antidote for the arid formalism of the late nineteenth century, a formalism which rested upon the delusion that law was more appropriately understood as a taxonomy of axiomatic concepts and doctrines. In a similar fashion, White's separationof-powers dissents reject that taxonomical approach to law. Doctrine was not irrelevant to White; rather, he considered doctrine as one of the facts to contend with in the ongoing creation of government.

One should begin to sense that rejecting formalism is not without its costs. Despite the sophisticated appeal of a functional appraisal of government structure, a constitutional doctrine molded to match one's vision of reality may impart its own sense of aridity by inviting the eventual evaporation of normative principles.

46. See generally KALMAN, supra note 4, at 3-44. 
Finally, legal realism was more than a rejection of formalism; it also promoted the reformist traditions of the Progressive movement and the New Deal's radical spin on progressivism. ${ }^{47}$ If one assumes, as the Progressives and New Dealers did, that government should operate as a positive, regulatory force in society, then the institutions of government must be structured to permit government to respond effectively to society's needs. A rigid structure may inhibit responsiveness, whereas a less formal structure would provide the government greater leeway in designing appropriate cures for social ills. White's separation-of-powers dissents reflect this progressive attitude; they promote a "modern government [able to] address a formidable agenda of complex policy issues," ${ }^{\prime 48}$ and adopt a functional analysis that permits the realization of that goal. The underlying assumption, of course, is that the goal of a progressive and activist government is a good thing.

\section{The Triumph of the Administrative State}

In his dissent in Bowsher v. Synar, Justice White referred to the "advent and triumph of the administrative state."49 These strong words indicate something more than acquiescence in the status quo. Indeed, for White, the administrative state was the primary feature of the new, evolving separation of powers, a fourth branch of government composed of experts charged with the federal supervision of our economy and our society. ${ }^{50}$ The seeds of White's confidence in the administrative state may well have been sown during his student days at Yale Law School where members of the faculty extolled the virtues and even the necessity of expert involvement in the formation of law and policy. ${ }^{51}$ That confidence remained unshaken throughout White's judicial career. $^{52}$

47. See HeRget, supra note 3, at 16470; Schlegel, supra note 3; G. Edward White, From Sociological Jurisprudence to Realism: Jurisprudence and Social Change in Early Twentieth-Century America, 58 VA. L. REV. 999 (1972).

48. Chadha, 462 U.S. at 999.

49. 478 U.S. 714, 761 (1986) (White, J., dissenting).

50. See Byron R. White, The State of the Law: The Bar's Responsibility, 17 Gonz. L. REv. 849, 85354 (1982). See generally Cass Sunstein, Constitutionalism After the New Deal, 101 HARV. L. REV. 421 (1987).

51. See, e.g., RODELL, supra note 5, at 263-68; Lasswell \& McDougal, supra note 4.

52. See, e.g., Lechmere, Inc. v. NLRB, 112 S. Ct. 841, 850-51 (1992) (White, J., dissenting); Dole v. United Steelworkers, 494 U.S. 26, 43-55 (1990) (White, J., dissenting); Sullivan v. Zebley, 493 U.S. 521, 541-42 (1990) (White, J., dissenting); NLRB v. Electrical Workers, 481 U.S. 573, 598-603 (1987) (White, J., dissenting); United States v. Riverside Bayview Homes, Inc., 474 U.S. 121 (1985) (White, J.); Chemical Mfrs. Ass'n v. Natural Resources Defense Council, 470 U.S. 116 (1985) (White, J.); Public Serv. Comm'n v. Mid-Louisiana Gas Co., 463 U.S. 319, 343-53 (1983) (White, J., dissenting); Charles D. Bonanno Linen Serv., Inc. v. NLRB, 454 U.S. 404 (1982) (White, J.); United States v. Swank, 451 U.S. 571, 585-95 (1981) (White, J., dissenting); EPA v. National Crushed Stone Ass'n, 449 U.S. 64 (1980) (White, J.); Detroit Edison Co. v. NLRB, 440 U.S. 301, 320-21 (1979) (White, J., dissenting); American Broadcasting Co. v. Writers Guild, 437 U.S. 411 (1978) (White, J.); NLRB v. Iron Workers, 434 U.S. 335 (1978) (White, J.); NLRB v. Pipefitters, 429 U.S. 507 (1977) (White, J.); Florida Power \& Light Co. v. International Bhd. of Elec. Workers, 417 U.S. 790, 813-14 (1974) (White, J., dissenting); NLRB v. Savair Mfg. Co., 414 U.S. 
Not too surprisingly, White's vision of the administrative state parallels his functional appraisal of the separation of powers. The pragmatic operation of the administrative state initially determines the scope of doctrine. Because an administrative state requires that experts resolve complex problems, legal doctrine must grant these experts the discretion necessary to accomplish their mission. Thus the necessity of expert judgment, and its function within the framework of shared power, defines the scope of the applicable separation-ofpowers doctrine and compels a doctrine of broad delegation and judicial deference. ${ }^{53}$ Contrariwise, if one had started with a rigid concept of separation of powers-strict rules of nondelegation - the administrative state would have been stillborn.

Functionalism, although permitting delegation and deference, does entail judicial oversight. ${ }^{54}$ As with the separation of powers, the judiciary determines whether the legislative or administrative scheme impinges upon core constitutional principles. Government must be structured to avoid the aggrandizement of power and the exercise of arbitrary authority. Alterations of the basic tripartite model are acceptable-including limitations on the scope of judicial review-as long as core principles remain in place.

Justice White demonstrated how the judiciary should check administrative agencies in his opinion for the Court in Motor Vehicle Manufacturers v. State Farm. ${ }^{55}$ In that case, the Court struck down an agency's attempt to rescind a regulation that would have required that manufacturers equip automobiles with airbags or automatic seatbelts. White's opinion presented a fact-intensive examination of the record that revealed the agency's failure to fully examine and appreciate the relevant data. ${ }^{56}$ While illustrating judicial oversight, the State Farm opinion also reflects, somewhat counter-intuitively, White's penchant for allowing administrative agencies broad latitude in judgment. For although the State Farm Court reversed the agency's attempted rescission, the Court provided the agency with the broadest possible discretion on remand. The agency could require the use of airbags, the use of automatic seatbelts, both, or neither, so long as the final decision was rational. ${ }^{57}$ In general, so

270, 281-82 (1973) (White, J., dissenting); Fribourg Navigation Co. v. Commissioner, 383 U.S. 272, 288300 (1966) (White, J., dissenting); NLRB v. Brown, 380 U.S. 278, 294 (1965) (White, J., dissenting).

53. FPC v. Florida Power \& Light Co., 404 U.S. 453, 463 (1972).

54. See, e.g., National R.R. Passenger Corp. v. Boston \& Maine Corp., 112 S. Ct. 1394, 1405-07 (1992) (White, J., dissenting); DeBartolo Corp. v. Florida Gulf Coast Bldg. \& Constr. Trades Council, 485 U.S. 568 (1988) (White, J.); ESTI Pipeline Project v. Missouri, 484 U.S. 495 (1988) (White, J.); Motor Vehicle Mfrs. Ass'n v. State Farm Mut., 463 U.S. 29 (1983) (White, J.); CBS v. FCC, 453 U.S. 367, $397-$ 418 (1981) (White, J., dissenting); Batterton v. Francis, 432 U.S. 416, $432-37$ (1977) (White, J., dissenting); Saxbe v. Bustos, 419 U.S. 65, 80-89 (1974) (White, J., dissenting).

55. 463 U.S. 29 (1983).

56. Id. at 51,56 .

57. Id. at 51,56 . 
long as administrative agencies act within a broadly defined area of reason and facts, White would respect their expert determinations. ${ }^{58}$

Justice White's "realistic" endorsement of the administrative state raises some philosophical concerns. Legal realism's belief that formalist doctrinal law often masks arbitrary power by lawyers, judges, and politicians collides headon with legal realism's asserted faith in the experts' ability to discover the true facts underlying social relationships and to devise appropriate remedies for a vast array of social ills. Advancing administrative law as a solution to social problems assumes that experts (and those interested in insulating expert judgment from the democratic process) will not fabricate doctrinal masks for the exercise of their own arbitrary power. Whether this faith is warranted is, at the very least, open to question. ${ }^{59}$ It may even be dangerous.

Yet Justice White's jurisprudence is more subtle than hard-line realism. ${ }^{60}$ For instance, his opinions in Chadha and State Farm recognize the need to check, both legislatively and judicially, the exercise of administrative power. His willingness to probe the decisions of individual agencies or administrators, however, was not accompanied by an equivalent willingness to question his general endorsement of the administrative state. Rather, he simply accepted the administrative state as a new and triumphant appendage to constitutional structure. It was "too late" to do otherwise. Yet a functional appraisal of the administrative state may have revealed that expert judgment can neither adequately assess the scope of social ills nor devise effective responses to those ills. It may have shown that centrally-planned solutions are not superior to market solutions. ${ }^{61}$

While it is not the judiciary's role to devise the country's economic theory, one would hope that judges would at least consider economic and social consequences before endorsing a massive alteration of constitutional structure. It may well be that despite the appeal of scientific thinking, our ability, even through experts, to appreciate and account for the complex dynamics that operate within the social structure is simply inadequate to the task of centralized planning. Seemingly rational planners may in fact adopt irrational

58. Cf. City of Cleburne v. Cleburne Living Ctr., 473 U.S. 432 (1985) (White, J.) (applying and enforcing rational basis standard under Fourteenth Amendment); San Antonio Indep. Sch. Dist. v. Rodriguez, 411 U.S. 1, 63-70 (1973) (White, J., dissenting) (arguing that school financing scheme is irrational and violates equal protection clause).

59. Fred Rodell's Woe Unto You, Lawyers!, which disparages the law as hocus pocus while extolling the virtues of expert judgment, presents an unintended expression of this incongruity. RODELL, supra note 5 , at 249-74.

60. Among other things, Justice White did not share the rather bleak view of lawyers espoused by some realists. See Byron R. White, Challenges for the U.S. Supreme Court and the Bar: Contemporary Reflections, 51 ANTITRUST L.J. 275, 276 (1982); White, supra note 50, at 867 (1982).

61. Friedrich Hayek suggests, in powerful terms, both the unworkability of a general model of centralized planning and the incipient threat to liberty and the rule of law posed by an undue reliance upon that model. FRIEDRICH A. HAYEK, THE ROAD TO SERFDOM 56-100 (1944) [hereinafter, HAYEK, THE ROAD TO SERFDOM]; see also FRIEDRICH A. HAYEK, THE CONSTITUTION OF LIBERTY 263 (1960); FRIEDRICH A. HAYEK, StUdiES IN PHILOSOPHY, POLITICS AND ECONOMICS 263-65 (1967). 
plans that nonetheless satisfy the doctrinal patina of the "hard look." If this less confident view of experts is correct, if it is the "reality" of the human condition, one would expect a less deferential doctrine of administrative law. ${ }^{62}$

Similarly, judicial acquiescence in the administrative state has precluded a tough constitutional examination of the conflict between the practice of centralized planning and the concept of individual liberty. While centralized planning is premised upon the notion that experts know best, individual liberty is premised upon the notion that individual choice in a competitive market provides not only the best economic solutions, but the optimum circumstances for human fulfillment and social development. The Court, including Justice White, has never confronted this conflict; instead it has acquiesced in an alteration of constitutional structure that may run counter to the liberal, individualistic premise of our constitutional system. Planning, regardless of its specific nature and consequences, is treated as a benign, unidimensional concept, subject only to a deferential judicial oversight. Assuming, as I do, that the truth involves a complicated accommodation of the extremes of central planning and absolute free choice, this limited judicial response may merit reconsideration as we move from the era of the New Deal and into the twentyfirst century. ${ }^{63}$

\section{FREEDOM OF EXPRESSION WITHIN THE POLITICAL STRUCTURE}

Constitutional law is sometimes thought of as raising two distinct types of issues, those involving the structure of government and those involving specific limitations on the exercise of otherwise legitimate power. The former typically addresses questions of separation of powers or federalism, the latter often concerns personal liberty. Naturally, the two types of issues-structure and limitation-intertwine: the form and function of government largely determines the scope of liberty interests, and a liberty interest cannot be defined adequately without commenting upon the government's form and function.

Justice White's First Amendment opinions often reflect this interrelationship of structure and limitation. Indeed, his analysis of freedom of speech and freedom of the press carries the same functionalist tone evidenced in his separation-of-powers and administrative law analysis. ${ }^{64}$ However, while White's administrative law jurisprudence often runs counter to basic concepts of classic liberalism such as individual choice, his First Amendment decisions, premised on a similar application of functionalism, quite often embody and promote those very same concepts.

62. Again, White's opinions in Chadha and State Farm do run contrary to the easy faith in administrative action, but those opinions go to the details and not the premises of the administrative state.

63. See Sunstein, supra note 50 , at 446-52, 463-79.

64. See discussion supra parts II, III. 
White's dissent in Buckley v. Valeo ${ }^{65}$ is illustrative. In Buckley, the Court addressed a wide array of constitutional challenges to the Federal Election Campaign Act Amendments of 1974. For present purposes, it is sufficient to note that the Court upheld the Amendment's limitations on contributions to candidates for federal office, but struck down the related expenditure limitations-independent expenditures, personal expenditures, and total expenditures-as inconsistent with the First Amendment. In arriving at the latter holding, the Court reasoned that limitations on expenditures were not justifiable because these limitations posed little potential for reducing electoral corruption, but greatly infringed on the First Amendment. ${ }^{66}$

Justice White dissented from this aspect of Court's holding. In sum, White weighed the structural concerns of preventing corruption, minimizing electoral costs, and promoting equity in the electoral system, against the limitations on political discourse and found expenditure limits constitutional.

His opinion begins with a strong affirmation of what he characterized as the "undoubted" power of Congress to prevent the corruption of the federal electoral process. ${ }^{67}$ Not surprisingly, White's instinct was to defer to the congressional judgment, not simply or even primarily because of Congress' role as the nation's lawmaker, but because of what White perceived as the practical, real-world experience that animated the passage of the Amendments:

Congress was plainly of the view that these expenditures also have corruptive potential; but the Court strikes down the provision, strangely enough claiming more insight as to what may improperly influence candidates than is possessed by the majority of Congress that passed this bill and the President who signed it. Those supporting the bill undeniably included many seasoned professionals who have been deeply involved in elective processes and who have viewed them at close range over many years. ${ }^{68}$

This pragmatic perspective, bolstered by a hard-edged tone, stays close to the surface throughout the dissent. As to the legitimacy of the ceiling on total campaign expenditures, White observed:

I have little doubt ... that limiting the total that can be spent will ease the candidate's understandable obsession with fundraising, and so free him and his staff to communicate in more places and ways unconnected with the fundraising function. There is nothing objectionable-indeed it seems to me a weighty interest in favor of the provision-in the attempt to insulate the political expression of federal candidates from the influence inevitably exerted by the endless

\footnotetext{
65. 424 U.S. 1 (1976).

66. Id. at $47-48$.

67. Id. at 257-58 (White, J., dissenting).

68. Id. at 261.
} 
job of raising increasingly large sums of money. I regret that the Court has returned them all to the treadmill. ${ }^{69}$

As this quotation suggests, for White, the First Amendment does not operate merely as a doctrinal trump on government power. First Amendment values are not independent constructs; rather, those values are integrated components of a political system, and as such they can only be defined as they function within that system. ${ }^{70}$

Viewed from this functional perspective, the limitation on expenditures is not so much a limitation on speech as it is a method of insulating the electoral process from what Congress deemed to be the corrupting influence of fundraising. It is, in short, a device designed to advance a classically liberal core value of the First Amendment, namely, the promotion of untainted political discourse within a competitive system of free expression.

White objected to the Court's doctrinal equation of money with speech. ${ }^{71}$ For White, the expenditure limitation did not directly regulate political speech, but a nonspeech element of the campaign process, the spending of money. Money, according to White, cannot be fairly equated with speech, at least not in terms of First Amendment values. While money does provide a means for engaging in speech, it does not follow that the regulation of the monetary aspect of the campaign process will in fact undermine such discourse. Congress, therefore, should be free to regulate expenditures so long as there is a substantial reason for doing so and the impact on political discourse is not overly burdensome. White thought these standards were satisfied. Congress' determination that expenditure limitations were necessary to curb the costs of elections, as well as to allay the perception that elections were being bought, represented to him a commonsense judgment entitled to judicial respect.

White accepted another structural consideration, namely, the congressional determination that contribution and expenditure limitations would roughly equalize the electoral process, ensuring that no candidate would have "overpowering advantage by reason of a huge campaign war chest." ${ }^{\text {.72 }}$ So long

69. Id. at 265 .

70. This view of the First Amendment as an integrated component of the political process is evident as well in Justice White's dissent in First National Bank of Boston v. Bellotti, 435 U.S. 765, 802-22 (1978). In that case the Court held unconstitutional a state statute that prohibited corporate contributions or expenditures related to ballot measures that did not materially affect the corporation. The limitation was deemed a direct restriction of political speech. Justice White's dissent did not view the case as creating a direct clash between governmental power and a First Amendment limitation on that power. Rather he saw the First Amendment as an integral part of both sides of the equation-on the one hand, the right of corporations to engage in speech, and on the other, the right of the state to prevent the state-sanctioned accumulation of corporate wealth to overwhelm the voices of individuals: "The Court's fundamental error is its failure to realize that the state regulatory interests in terms of which the alleged curtailment of First Amendment rights accomplished by the statute must be evaluated are themselves derived from the First Amendment." Id. at 803-04.

71. Buckley, 424 U.S. at $262-63$.

72. Id. at 265 . 
as the expenditure ceiling was not "plainly too low," White would respect the practical wisdom of Congress to devise an improved electoral model. ${ }^{73}$

Justice White's Buckley dissent frames the functional approach in a positive light. ${ }^{74}$ Even if one disagrees with White's conclusions, the theme of his opinion-restoring actual competition to the electoral process-has its own positive attraction. Yet one can view the First Amendment as a functional component of a system of government and still arrive at conclusions that may undermine or even eviscerate the utility and value of free expression within that system. Of itself, functionalism does not promote a particular substantive outcome. It does not define or promote particular values; rather, it provides a tool for examining law from a factual and realistic perspective. Such a fact- or transaction-based examination of law should help expose the values and policy judgments that lurk behind legal concepts and judicial decisions. Similarly, functionalism can be used as a rhetorical device to promote particular values or policy judgments. ${ }^{75}$ But in the end the inherent "value" to be found in the functional approach is the value of understanding how the law operates to promote or disparage other substantive values within particular factual contexts. Thus, although the Buckley dissent is persuasive testament for approaching the First Amendment as a component of an all-encompassing political system-in part because of the attractiveness of the normative values White sought to promote-it does not follow that all applications of functionalism will satisfy any particular normative value of free expression.

Branzburg v. Hayes ${ }^{76}$ effectively illustrates the nonideological nature of functionalism. Branzburg involved a reporter's refusal to divulge confidential sources to a grand jury. Claiming that the information was privileged, the reporter phrased his First Amendment argument in functional terms: reporters gather information through confidential sources; these confidential sources remain available only to the extent they can be assured continued confidentiality. This system provides reporters with the raw material needed to write the news which, in turn, is vital to inform the public. In this manner, the news-gathering system, including the privileged identity of the informant, advances the public's right to know, a core value of the First Amendment.

Writing for the Court, Justice White did not find this argument persuasive. The reporter's system was not a separate, dispositive construct that by its own force could give rise to a constitutional privilege. Rather, for White, the newsgathering process was one part of a social and governmental landscape that

73. Id. at 265-66.

74. Accord Federal Election Comm'n v. National Conservative Political Action Comm., 470 U.S. 480 , 502-18 (1985) (White, J., dissenting); Citizens Against Rent Control v. City of Berkeley, 454 U.S. 290, 303-11 (1981) (White, J., dissenting).

75. The current debate over speech codes is a case in point. Compare Nadine Strossen, Regulating Racist Speech on Campus: A Modest Proposal, 1990 DUKE L.J. 484 with Charles R. Lawrence III, If He Hollers Let Him Go: Regulating Racist Speech on Campus, 1990 DUKE L.J. 431.

76. 408 U.S. 665 (1972). 
contained a legitimate law enforcement system which included grand jury investigations. While the public had an interest in the free flow of information, the public also had an equally strong claim to an effective system of law enforcement. ${ }^{77}$

Again, White examined the historical and contemporary function at issue, in this case the reporter's privilege and the First Amendment. Historically, there was no reporter's privilege largely because the grand jury's dual function-finding probable cause to prosecute and protecting citizens against unfounded charges-required both a broad investigative authority and the full participation of all citizens called upon to testify. ${ }^{78}$ "From the beginning of our country the press has operated without constitutional protection for press informants, and the press has flourished. The existing constitutional rules have not been a serious obstacle to either the development or retention of confidential news sources by the press." ${ }^{.79}$ Even in today's world, White was not convinced that the absence of a reporter's privilege would encumber the press' ability to function as a conduit of information to the public. The record contained no convincing evidence that sources of information would disappear without the privilege. "Estimates of the inhibiting effect of such subpoenas on the willingness of informants to make disclosures to newsmen are widely divergent and to a great extent speculative." ${ }^{80}$ White also declined to assume that all, or even most, confidential sources would provide information likely to be of interest to a grand jury investigation; indeed, the only confidential sources who might be affected by the lack of privilege were those who had either committed a crime or had witnessed a crime. The former were entitled to no special consideration, and the reporter, like all citizens, had an obligation to testify to crimes witnessed. The argument for a privilege to protect witnesses to a crime stood on a slightly better footing-it was not irrational—but the Court found no adequate factual support for the reporter's contention that such sources would refuse to come forward. And even assuming some informants would refuse, the public's interest in prosecuting and deterring crime would take precedence over any such claim..$^{81}$ In White's words, "it is obvious that agreements to conceal information relevant to commission of crime have very little to recommend them from the standpoint of public policy." 82

Justice White also pointed to other elements within the system that militated against the creation of a constitutional privilege:

\footnotetext{
77. Id. at $686-88$.

78. Id. at 685-87.

79. Id. at 698-99.

80. Id. at 693-94 (citation omitted).

81. Id. at 695-97.

82. Id. at 696 .
} 
Neither are we now convinced that a virtually impenetrable constitutional shield, beyond legislative or judicial control, should be forged to protect a private system of informers operated by the press to report on criminal conduct, a system that would be unaccountable to the public, would pose a threat to the citizen's justifiable expectations of privacy, and would equally protect well-intentioned informants and those who for pay or otherwise betray their trust to their employer or associates. ${ }^{83}$

If such a privilege were to be created it would be better left to the hands of Congress or the state legislatures. Those entities possess the political authority and the institutional competence to address this issue. ${ }^{84}$ Finally, White struck a decidedly realist theme by observing that the creation of a reporter's privilege would "obstruct the search for truth." 85 After all, if facts are the critical foundation for a realistic appraisal of legal controversies, limitations on the fact-finding process potentially undermine that endeavor. ${ }^{86}$

The significance of White's opinion in Branzburg does not lie in its rejection of a reporter's privilege, but in the manner in which that privilege was denied. White dismantled the functional argument in favor of a privilege in three ways, all of which underscore White's function- and fact-oriented approach to jurisprudence. First, by refusing to encapsulate the issues within the relatively narrow confines of the news-gathering perspective, White transformed the functional argument of the reporter into a functional argument against the reporter. In essence, White said, "Let's look at this from another somewhat more comprehensive perspective." Second, taking the reporter's argument at face value, White attempted to show that its functional depiction of reality-a system of information gathering and the resulting free flow of information-was inaccurate. The facts did not sustain the claim. Finally, extending the argument from function to policy, White asserted that no sound policy reason supported the judiciary's creation of a privilege that would interfere with the fact-intensive process of investigating crime. These themes-function, fact, and policy-are at the very heart of White's jurisprudence.

The application of this methodology, however, does not lead to obvious or ideologically consistent results. Justice Stewart's dissent in Branzburg, also premised upon functionalism, offers a strong counterpoint to Justice White's opinion. ${ }^{87}$ In the beginning of his dissent, Stewart passionately endorsed the vital role played by the press in a free and democratic society. He stated that the right to publish, and the corollary right to gather news, are absolutely
83. Id. at 697.
84. Id. at 706 .
85. Id. at 690 n.29.
86. See FRANK, supra note 4, at 14-16.
87. 408 U.S. at 725-52 (Stewart, J., dissenting). 
essential to the survival of our social and political system. ${ }^{88}$ Furthermore, he argued, the right to gather news necessarily includes "a right to a confidential relationship between a reporter and his source," since an "unbridled subpoena power" would undermine the reporter's ability or willingness to gather or publish information. ${ }^{89}$ Stewart reinforced this commonsense judgment about the effect of broad subpoena power with what he described as "concrete evidence," citing numerous studies supporting his view. ${ }^{90}$ Although individually these studies did not, and probably could not, offer scientific precision, taken together they were sufficiently probative to indicate that the absolute lack of a reporter's privilege would, in fact, restrict the flow of information to the public. Balancing society's interest in law enforcement against society's interest in the free flow of information, Stewart concluded that some type of judicially created privilege was necessary. ${ }^{91}$

There are three critical distinctions between the White and Stewart opinions in Branzburg. First, the interpretation of the facts varied between White's view that the lack of a privilege would have little effect on the flow of information to the public and Stewart's contrary conclusion that the impact . would be great. Both conclusions are necessarily based on broad speculations going well beyond the actual facts of the case before the Court, making it virtually impossible to determine which is correct. Although reliance on empirical proof is within the realist tradition, the empirical proof available to the Court was far from dispositive. Second, White's opinion emphasized the critical role of the grand jury, while Stewart's opinion emphasized the critical role of the First Amendment. Which function should be given dominant constitutional consideration depends upon a policy judgment made by the judge. Functionalism provides no normative measure to determine which policy judgment is more correct. The value is imparted by the judge. Finally, given the broad ramifications of a reporter's privilege, White saw the legislative branch as the appropriate vehicle for the creation of such a privilege, while Stewart saw the judiciary as responsible for making that policy judgment. Again, although functionalism recognizes that the judiciary will make policy decisions, functionalism provides only perspectives from which to argue the propriety or impropriety of such action.

But the nonideological nature of functionalism does not make it illegitimate. On the contrary, properly executed, the functional approach exposes the premises upon which a decision rests and provides a thorough basis for evaluating the decision. The doctrine or policy that underlies a judicial opinion is dispositive only to the extent that the opinion demonstrates a nexus between that policy and the particular context and configuration of the

88. Id. at $726-27$.

89. Id. at 728 .

90. Id. at 732-33 \& nn.12-16.

91. Id. at 736-43. 
dispute at hand. Indeed, perhaps one of the most dissatisfying aspects of both White's and Stewart's opinions is that both rely on factual generalizations and idiosyncratic applications of common sense. As such, neither opinion emerges as clearly "right" on the wisdom or necessity of creating a reporter's privilege. However, the lack of conclusive facts about the impact of grand jury subpoenas upon the flow of information and the converse impact of a reporter's privilege upon the grand jury process may lean in favor of White's deference to the legislative process. This deference to legislative competence is reminiscent of White's administrative law decisions and lies at the heart of legal realism: the institutional capacity of the judiciary to discover facts beyond those of an immediate case or controversy is inadequate for making broad policy judgments that necessarily rely upon a more inclusive fact-finding process.

In The Pentagon Papers Case, ${ }^{92}$ White again relied on the integration of free expression and governmental structure in his concurring opinion. Indeed, from White's perspective, one could just as easily categorize Pentagon Papers as a separation-of-powers case. Pentagon Papers involved a lower court's injunction against the New York Times' publication of secret government documents. The Court held that the injunction was improper, and White agreed. White based his conclusion on the heavy presumption against prior restraints, a presumption he deemed inherent in the First Amendment, and upon concerns regarding the vast, virtually unchecked power of the executive in the realm of national defense. ${ }^{93}$ Again we see limitation and structure fusing into a functional whole. In essence, the presumption against prior restraints, which allowed the newspaper to publish, operated as a check upon the exercise of executive power in this otherwise unchecked domain. ${ }^{94}$ Therefore, despite his view that the publication would damage the public interest, White refused to permit the executive to eviscerate the sole functional method of constitutional oversight.

As should be evident, White's reasoning goes beyond simple obeisance to an abstract concept of the First Amendment. White was not entranced by the freedom of the press; rather he was searching for a functional means to keep the tripartite system in balance. For example, had Congress required a joint judgment of all three branches to impose injunctions against publishing national security information, White hinted that he might have permitted a prior restraint. ${ }^{95}$ Such a scenario would lessen if not eliminate any concerns regarding the exercise of arbitrary power, thereby reducing the need for the

92. New York Times v. United States, 403 U.S. 713 (1971).

93. Id. at 730-32 (White, J., concurring).

94. This theme is more explicit in Justice Stewart's concurring opinion, which Justice White joined. Id. at 727-28.

95. Id. at 731 (White, J., concurring) (stating that "express and appropriately limited congressional authorization," a prior restraint may be permissible). 
press, via the First Amendment, to act as a check. Similarly, White distinguished between the judicial reluctance to sanction prior restraints and a judicial willingness to permit criminal prosecutions once the papers are published..$^{96}$ Not only are the criminal sanctions authorized by Congress, but the dissemination of the information places the controversy before the public and under judicial scrutiny, and permits the establishment of relatively clear guidelines for future actions. Again, given joint action by the three branches, as well as public scrutiny, the need for an absolutely unrestrained press is less evident.

The distinction between prior restraints and criminal prosecutions also places some responsibility in the lap of the checking institution-the press. Under a system in which prior restraints are disfavored, the press and not the President will exercise the judgment on whether to publish, subject of course to the threat of subsequent criminal prosecution-a check on the press maintained by the executive. Thus while the executive cannot prevent publication of embarrassing materials, it may prosecute the publication of secret materials when that publication is both damaging to the national interest in a manner specified by Congress and in a manner the executive deems consistent with judicial and public judgment regarding the need for secrecy in the context of national security.

Of course, this functionalist approach may cause no little consternation for the press. The foreboding tone of Justice White's opinion was surely not lost on those charged with the decision of which of the Pentagon Papers to publish. From the perspective of the press, the absolute limitation approach advocated by Justice Black in his Pentagon Papers concurrence ${ }^{97}$ was surely preferable to the more risky and complicated scenario suggested by Justice White. ${ }^{98}$ Yet under Black's model the press remains completely unaccountable for its actions, a proposition that Justice White was unwilling to accept. Indeed, in several contexts, Justice White clarified his view that despite the large realm of freedom enjoyed by the press, that freedom does not include the unchecked authority to act irresponsibly. ${ }^{99}$ His opinion in Branzburg was, of course, premised on this same conception of freedom and responsibility.

The foregoing discussion focused on Justice White's use of an integrated, functional approach to the assessment of controversies implicating the freedom of expression; White used the same approach in the realm of separation of powers. These opinions demonstrate that the distinction between structure and

96. Id. at $733-40$.

97. Id. at 714-20.

98. Id. at $730-40$ (White, J., concurring).

99. See, e.g., The Florida Star v. B.J.F., 491 U.S. 524, 542-53 (1989) (White, J., dissenting) ("While I would not want to live in a society where freedom of the press was unduly limited, I also find regrettable an interpretation of the First Amendment that fosters such a degree of irresponsibility on the part of the news media."); Herbert v. Lando, 441 U.S. 153 (1979); Gertz v. Robert Welch, Inc., 418 U.S. 323, 369-404 (1974) (White, J., dissenting). 
limitations is merely for doctrinal convenience and does not accurately portray reality. White's use of functionalism was something more than a neutral deconstruction of doctrinal lines, however. Functionalism necessarily carries a value judgment regarding the nature of law; that is, the functionalist sees law as a reflection of power relationships arising in factual contexts rather than as a set of immutable rules to be discovered through judicial introspection. White's use of functionalism exposed those specific values he deemed worthy of promotion within that system of power relationships. Thus White's dissents in the election financing cases reveal his belief that in elections the quality of public discourse has greater constitutional value than the individual's freedom to spend one's money as one wishes. Similarly, the Branzburg opinion places a premium on protecting the fact-discovery process of the criminal justice system, based on the policy judgment that the needs of that system outweigh a reporter's need to protect confidential sources. The Pentagon Papers concurrence values pragmatic workability and individual responsibility over broad conceptions of absolute power or absolute freedom. Obviously, whether one accepts or rejects White's value judgments will influence any normative evaluation of White's jurisprudence. Together, his value judgments form a conception of our political system. More importantly, however, this section of the Essay demonstrates that the judicial function necessarily involves the promotion of value judgments both about what law is and what law ought to do.

White's freedom-of-expression and separation-of-powers decisions are similar in that they use a functionalist methodology. They differ, however, in the values they promote. White's administrative law opinions validate centralized planning and support the significant restructuring of government necessary to allow such centralization. In supporting centralized, collective choice, White places a lower priority on individual freedom, the central value of liberal philosophy. In contrast, White's First Amendment decisions promote the liberal values of individual freedom and personal responsibility within a competitive market system. Government is permitted to regulate, but that regulation is designed to ensure that the market remains free, competitive, and responsible, a type of regulation resting upon decidedly liberal premises and quite consistent with the liberal rule of law. ${ }^{100}$ Thus the consistency of analytical approach-functionalism-belies a divergence of concepts.

\section{Liberal VALUES AND the Policy of Desegregation}

When Justice White began his tenure on the Court in April 1962, Brown v. Board of Education ${ }^{101}$ was just short of its eighth anniversary, yet the "all

100. See HAYEK, THE ROAD TO SERFDOM, supra note 61 , at 36-42.

101. 347 U.S. 483 (1954). 
deliberate speed" command of Brown $I I^{102}$ still faced formidable resistance throughout the nation. As the Deputy Attorney General during a volatile period of the civil rights movement, ${ }^{103}$ White was fully aware of that resistance; as a member of the Court, his opinions and votes moved toward implementing the Brown mandate. White strongly endorsed the desegregation promise because he believed that the primary purpose of the Fourteenth Amendment was to secure the civil rights of black citizens. His observations and experiences as Deputy Attorney General undoubtedly bolstered the strength of that conviction.

By 1971, Justice White had joined several opinions either striking down various devices and schemes designed to avoid the constitutional duty to desegregate ${ }^{104}$ or granting lower courts ample authority, and even imposing the duty, to implement effective, immediate, and broad-based remedies designed for dismantling segregated school systems. ${ }^{105}$ Justice White's first written opinion on desegregation came not in a school case, however, but in Palmer v. Thompson, ${ }^{106}$ a case involving the closure of public swimming pools by the city of Jackson, Mississippi. Both the strong tone of White's language and his fact-intensive assessment of the case provide a clear portrait of his judicial disposition in the realm of civil rights.

Jackson operated its swimming pools on a segregated basis in flagrant violation of post-Brown decisions requiring desegregation of such public facilities. ${ }^{107}$ In 1962, a lawsuit challenged this practice and resulted in a judgment ordering the city to desegregate its recreational facilities, including its pools. Instead of opening the pools to both races, however, the city closed all public pools, professing a belief that integrated pools could not be operated on a safe and economic basis. The Supreme Court found no constitutional violation in the closure of the pools. The closure itself was racially neutral and, therefore, consistent with the equal protection guarantee; moreover, the Court deemed the consideration of any alleged illicit motive on behalf of the city as beyond the Court's competence. ${ }^{108}$ Justice White dissented. ${ }^{109}$

102. 349 U.S. 294,301 (1955).

103. Eyes on the Prize, Part I (PBS television broadcast, 1987) (documenting White's involvement in civil rights controversies as Deputy Attorney General).

104. Monroe v. Board of Comm'rs, 391 U.S. 450 (1968) (holding that free-transfer plan does not satisfy duty to desegregate); Raney v. Board of Educ., 391 U.S. 443 (1968) (holding that freedom-of-choice plan does not satisfy duty to desegregate); Green v. County Sch. Bd., 391 U.S. 430 (1968) (same); Griffin v. County Sch. Bd., 377 U.S. 218 (1964) (holding that closure of public schools and system of grants for white students to attend private segregated schools perpetuates unlawful segregation); Goss v. Board of Educ., 373 U.S. 683 (1963) (holding that free-transfer plan violates equal protection guarantee of Fourteenth Amendment).

105. Davis v. Board of Sch. Comm'rs, 402 U.S. 33 (1971); Swann v. Charlotte-Mecklenburg Bd. of Educ., 402 U.S. 1 (1971); Northcross v. Board of Educ., 397 U.S. 232 (1970); Alexander v. Holmes County Bd. of Educ., 396 U.S. 19 (1969).

106. 403 U.S. 217 (1971).

107. See, e.g., Gayle v. Browder, 352 U.S. 903 (1956) (per curiam) (city buses); Holmes v. Atlanta, 350 U.S. 879 (1955) (per curiam) (municipal golf course); Mayor of Baltimore v. Dawson, 350 U.S. 877 (1955) (per curiam) (public beaches and bathhouses).

108. Palmer, 403 U.S. at 224-26. 
Whereas the majority opinion adopted a formal approach to the constitutional issues-since the pool closing was, on its face, race-neutral the equal protection guarantee was not implicated-Justice White's dissent looked to the factual realities of the event. His dissent is fact-intensive and valueladen. It describes the post-Brown history of judicial efforts to desegregate public facilities as well as the parallel history of resistance to those efforts. Relying on record facts, it depicts the City of Jackson as essentially a paradigm of that resistance. ${ }^{110}$ Looking beyond the facial neutrality of the city's action, White saw both the illicit motive, which he deemed constitutionally significant, and the "reality" of the disproportionate impact upon the minority community, including the implicit message to that community concerning the cost of attempting to enforce constitutional rights. "I The facts led White to conclude that the decision to close the pools was precipitated by the order to desegregate; indeed, the decision was nothing more than a means to avoid compliance with a lawful court order and, in the process, to denigrate the race for whom the Fourteenth Amendment had been adopted. ${ }^{112}$ White also rejected, as unsupported by anything other than gross speculation, the city's assertion that the pools could not be safely or economically operated on an integrated basis. Taking all these facts together, White concluded that the closure of the pools violated the Equal Protection Clause. In his words, "a State may not have an official stance against desegregating public facilities and implement it by closing those facilities in response to a desegregation order." 113

With a marked similarity to his assessment of legal rules and principles in areas previously discussed, White's approach to the law of equal protection did not elevate the niceties of doctrine over the realities of circumstance. If the Fourteenth Amendment is designed to protect the civil rights of blacks-a value that White clearly deemed of utmost importance-then the Equal Protection Clause must be interpreted to provide that protection in practice. Just as the key to understanding the separation of powers is an awareness of how the government actually functions, the key to understanding the Equal Protection Clause is an appreciation of the actual dynamics perpetuating violations of civil rights. In short, the law, particularly constitutional law, must be construed in a manner that reflects, as nearly as possible, an accurate appraisal of reality. In Palmer, White interpreted the closure of the pools as an intentional denigration of the black community; that being the case, neither deference to the judgment of city officials nor reliance upon nice distinctions

109. Id. at 240-71 (White, J., dissenting).

110. Id. at 243-54.

111. Id. at 261-70.

112. Id. at $266-67$.

113. Id. at 240. 
of doctrine could alter his perception that the city's conduct violated the Equal Protection Clause.

Justice White again exhibited his realistic appraisal and doctrinal flexibility in Milliken $v$. Bradley. ${ }^{114}$ In a five-to-four decision, the Court held that a district court could not order a multidistrict remedy for school desegregation in the absence of a showing that the violations of equal protection actually crossed district lines, in this case throughout the Detroit metropolitan area. ${ }^{115}$ In dissent, White rejected the formal distinction between state-created districts and noted that, in any event, the equal protection violation belonged to the state. ${ }^{116}$ The following quotation captures the essence of his dissent:

Despite the fact that a metropolitan remedy, if the findings of the District Court accepted by the Court of Appeals are to be credited, would more effectively desegregate the Detroit schools, would prevent resegregation, and would be easier and more feasible from many standpoints, the Court fashions out of whole cloth an arbitrary rule that remedies for constitutional violations occurring in a single Michigan school district must stop at the school district line. Apparently, no matter how much less burdensome or more effective and efficient in many respects, such as transportation, the metropolitan plan might be, the school district line may not be crossed. Otherwise, it seems, there would be too much disruption of the Michigan scheme for managing its educational system, too much confusion, and too much administrative burden.

The District Court, on the scene and familiar with local conditions, had a wholly different view. ${ }^{117}$

In short, judicially created remedies, like the underlying constitutional violations, ought to fairly and accurately address the actual circumstances presented by the controversy, rather than rely upon some artificial demarcation created by the state and given judicial blessing in the service of doctrine.

Five years later, Justice White wrote majority opinions in two cases involving claims of systemwide segregation in urban school districts. In Columbus Board of Education v. Penick ${ }^{118}$ and Dayton Board of Education v. Brinkman, ${ }^{119}$ the Court affirmed the lower courts' findings that the school boards had taken action to segregate students on the basis of race, and upheld the imposition of broad remedial measures. State law did not mandate segregation and no smoking gun of illicit intent was evident. White's opinions, however, permitted the lower courts to infer such intent based in part upon the

114. 418 U.S. 717 (1974).

115. Id. at $744-45$.

116. Id. at 763 (White, J., dissenting).

117. Id. at 767-68 (footnote omitted).

118. 443 U.S. 449 (1979).

119. 443 U.S. 526 (1979). 
foreseeable effects of the school boards' actions. In so doing, White satisfied the Court's holding in Washington $v$. Davis, ${ }^{120}$ which he authored, that required a showing of purposeful discrimination as an essential element of an equal protection violation. White was quite willing to discover that intent through a flexible appraisal of the circumstances. Again, reality, as opposed to formal doctrine, was the controlling principle.

Recently, in Missouri v. Jenkins, ${ }^{121}$ Justice White again demonstrated his willingness to confer broad discretion upon district courts. In that case, the district court entered a school desegregation order that included the imposition of a substantial property tax increase. The court order included the tax increase because state law precluded local officials from imposing the type of tax thought necessary to finance the desegregation plan. The desegregation plan was both innovative and expensive. The state was not simply required to reassign students among its existing schools; rather, the plan required the creation of magnet schools that would attract a racially diverse student body. ${ }^{122}$ Under the plan, eighteen existing school facilities would be closed and seventeen new facilities would be created throughout the district. The new facilities included a twenty-five acre farm and a twenty-five acre wildland area. ${ }^{123}$ The total cost would be $\$ 260,000,000$.

Writing for the Court, Justice White found that the judicially imposed tax increase violated principles of comity and was, accordingly, an abuse of discretion. ${ }^{124}$ The Court's opinion went on to hold, however, that the district court could order the local officials to raise taxes and then enjoin enforcement of the state laws that limited local authorities from doing so. In so holding, the Court rejected the state's argument that a court could only order local officials to impose taxes in a manner consistent with state law. White explained that state law could not stand as an impediment to the duty to comply with the Fourteenth Amendment. ${ }^{125}$ Thus while the Milliken Court limited available desegregation remedies by relying on distinctions created by state law, the Jenkins Court refused to be bound by such distinctions, and adopted an approach much closer to that advocated by Justice White in his Milliken dissent. Moreover, Jenkins indirectly confirmed that district courts are not

120. 426 U.S. 229 (1976). White's adherence to the intent requirement was based largely on his view that the purpose of the Fourteenth Amendment and supporting civil rights legislation was to remedy state laws and state action specifically designed to harm black Americans. City of Memphis v. Greene, 451 U.S. $100,129-35$ (1981) (White, J., concurring). The holding in Washington $v$. Davis could be characterized as imposing a doctrinal straitjacket on resolving problems of racial discrimination; however, given the realism with which Justice White applied the purposeful discrimination standard, such a characterization seems inaccurate. See his majority opinion in Rogers v. Lodge, 458 U.S. 613 (1982). See also City of Mobile v. Bolden, 446 U.S. 55, 94-103 (1980) (White, J., dissenting).

121. 495 U.S. 33 (1990).

122. Jenkins v. Missouri, 855 F.2d 1295, 1301 (8th Cir. 1988).

123. Id. at 1301,1306 .

124. 495 U.S. at 50-52.

125. Id. at 57 . 
bound by preconceived notions of how to dismantle a segregated school system. The district court's creative plan suggests that the best solutions will be discovered not through rules imposed by the Supreme Court, but through the decentralized and innovative judgment of district courts, a judgment informed by an intimate knowledge of the facts and circumstances of the case.

Justice White's desegregation decisions testify to his conviction that the Brown mandate, which he interpreted to require the dismantling of all systems of de jure segregation, must be fully and effectively honored. ${ }^{126}$ At the heart of this commitment to desegregation was White's belief that the Fourteenth Amendment was designed to protect the civil rights of black Americans against invidious and discriminatory state action. He applied that principle in a fashion that went beyond formalism and attacked what he perceived to be the practical realities of race discrimination. The power of federal courts in this specific regard was as broad as was necessary to remedy the underlying violation. That power was not totally centered on the Supreme Court; rather, district courts' had broad discretion which was checked by a deferential Supreme Court review. In sum, led by Justice White, the Court created a functional system much like the one White envisioned in the context of the separation of powers.

There is, however, an important distinction. In the context of separation of powers (and administrative law), the underlying value is a belief in activist government. Of course, that same belief is seen in White's willingness to grant district court judges broad discretion in fashioning desegregation remedies. But the value behind that latter grant of discretion is not simply a general approbation of governmental activism, but an endorsement of activism in a specified context, a context driven by more precise values, namely, the full participation of all citizens in the social, economic, and political process. In short, much like Justice White's approach to freedom of expression, his approach to equal protection is premised on maximizing individual freedom within the political and economic marketplace. The federal judiciary's remedial power is a means to that end.

126. White's vision of the Fourteenth Amendment did not endorse judicial action beyond the dismantling of de jure systems of segregation. See Freeman v. Pitts, $112 \mathrm{~S}$. Ct. 1430 (1992) (White joins Court opinion permitting district court to relinquish supervision and control of school district in incremental stages before full compliance has been achieved in all areas of school operations); Board of Educ. v. Dowell, 111 S. Ct. 630 (1991) (White joins Court opinion holding that district court may dissolve desegregation decree if vestiges of past discrimination have been eliminated to extent practicable); Crawford v. Board of Educ., 458 U.S. 527 (1982) (White joins Court opinion upholding state constitutional provision that does not permit forced busing other than to remedy violations of Fourteenth Amendment); Pasadena Bd. of Educ. v. Spangler, 427 U.S. 424 (1976) (White joins Court opinion holding that district court exceeded its authority by ordering school district that had achieved unitary system to readjust attendance zones based on shifting populations). $C f$. Washington v. Seattle Sch. Dist. No. 1, 458 U.S. 457 (1982) (White joins Court opinion striking down state measure that used racial nature of issue-desegregative busing- to define governmental decisionmaking structure). 


\section{FundameNTAL Rights AND THE AGENDA OF A MODERN GOVERNMENT}

A slightly different picture emerges in the context of nontextual fundamental rights. Because White generally favored legislative solutions and judicial nonintervention, as demonstrated in his separation-of-powers and administrative law decisions, he usually avoided the judicial creation of protected interests. ${ }^{127}$ Under what he deemed appropriate circumstances, however, Justice White was willing to extend the scope of constitutional protection. For example, he joined the Court's opinion in Reynolds v. Sims ${ }^{128}$ extending the equal protection clause to cover the one-person, one-vote principle, and he adhered to that principle throughout his career. ${ }^{129} \mathrm{He}$ stated his reasons for so doing succinctly and in classic liberal terms in Board of Estimate v. Morris: ${ }^{130}$

These cases are based on the propositions that in this country the people govern themselves through their elected representatives and that "each and every citizen has an inalienable right to full and effective participation in the political processes" of the legislative bodies of the Nation, State, or locality as the case may be. ${ }^{131}$

Overall, however, White recognized that the judicial extension of constitutional law would interfere with the preferable legislative or administrative solutions to problems of social policy. Even in the one-person, one-vote context, White expressed concern that a mathematically rigid application of the doctrine would promote unnecessary interference with legitimate legislative judgment. ${ }^{132}$

127. But compare Robinson v. California, 370 U.S. 660, 685-89 (1962) (White, J., dissenting) (criticizing Court for broad construction of cruel and unusual punishment clause in context of narcotics use) with Ingraham v. Wright, 430 U.S. 651, 683-700 (1977) (White, J., dissenting) (criticizing Court for narrow construction of cruel and unusual punishment clause in context of student corporal punishment).

128. 377 U.S. 533 (1964).

129. Board of Estimate v. Morris, 489 U.S. 688 (1989) (White, J.) (enforcing one-person, one-vote rule); Karcher v. Daggett, 462 U.S. 725, 765-83 (1983) (White, J., dissenting) (objecting to Court's equality requirement as more precise than statistical inaccuracy of census count); Ball v. James, 451 U.S. 355, 37489 (1981) (White, J., dissenting) (objecting to Court's one-acre, one-vote rule); White v. Weiser, 412 U.S. 783 (1973) (White, J.) (applying relatively rigid one-person, one-vote standard to congressional districts); White v. Regester, 412 U.S. 755 (1973) (White, J.) (adopting more flexible standard for state legislative districts than for congressional districts); Gaffney v. Cummings, 412 U.S. 735 (1973) (White, J.) (holding that minor deviations do not make out prima facie violation of equal protection); Ely v. Klahr, 403 U.S. 108 (1971) (White, J.) (affirming district court invalidation of apportionment plan); Phoenix v. Kolodziejski, 399 U.S. 204 (1970) (White, J.) (finding vote on general obligation bonds may not be limited to owners of real property); Wells v. Rockefeller, 394 U.S. 542, 553-56 (1969) (White, J., dissenting) (objecting to Court's mathematically inflexible standards); Avery v. Midland County, 390 U.S. 474 (1968) (White, J.) (extending Reynolds to local governmental units); Swann v. Adams, 385 U.S. 440 (1967) (White, J.) (applying Reynolds to nonminor variations in voting disparities).

130. 489 U.S. 688 (1989).

131. Id. at 693 (quoting Reynolds v. Sims, 377 U.S. 533, 565 (1964)).

132. Karcher v. Daggett, 462 U.S. $725,765-83$ (1983) (White, J., dissenting); Wells v. Rockefeller, 394 U.S. 542, 553-56 (1969) (White, J., dissenting). 
These general observations, however, merely describe a broad landscape; they require specific exploration. ${ }^{133}$

The right of privacy is, for the present generation, the quintessential nontextual right, including within its amorphous contours the good, the bad, and the ugly of judicial review. It is both the destroyer of judicial careers and the altar upon which such careers are sanctified. Depending on one's perspective, constitutional privacy represents either the evil reincarnation of Lochner and substantive due process or the wise and judicious extension of constitutional principles to a realm of activity that ought to be free from governmental interference. Of course, it's more complicated than that. Justice White's opinions reflect much of the internal tension found within the jurisprudence of privacy. A fruitful place to begin an examination of Justice White's response to the right of privacy is Griswold $v$. Connecticut, ${ }^{134}$ a case involving a challenge to Connecticut's anti-contraceptive statute.

The six opinions in Griswold underscore both the richness and the evanescence of constitutional law. Justice Douglas' opinion for the Court offers his well known and somewhat loopy tour de force of penumbras and invisible emanations from which he conjured an amorphous, but potent right of privacy. ${ }^{135}$ Justice Goldberg presented a theory of an enforceable Ninth Amendment, ${ }^{136}$ while Justice Harlan argued that privacy is implicit in the concept of ordered liberty. ${ }^{137}$ Justice Black submitted a powerful dissent based upon the absence of a specific textual guarantee of privacy, ${ }^{138}$ and Justice Stewart roundly criticized the reasoning in the Douglas and Goldberg opinions. ${ }^{139}$ Justice White wrote an opinion concurring in the judgment. ${ }^{140}$

Justice White agreed that the anti-contraceptive statute at issue in Griswold infringed upon a constitutionally protected liberty interest, one that he broadly defined as involving the intimacies of the marriage relationship. His treatment of the issue was cryptic: "It would be unduly repetitious, and belaboring the obvious, to expound on the impact of this statute on the liberty guaranteed by the Fourteenth Amendment against arbitrary or capricious denials or on the nature of this liberty." "141 Since, in White's view, the statute invaded the marital relationship in a significant way, the state bore "a substantial burden

133. White was also willing to put some teeth in the rational basis test. See, e.g., City of Clebume v. Cleburne Living Ctr., 473 U.S. 432 (1985) (White, J.); New York Transit Auth. v. Beazer, 440 U.S. 568, 597-611 (1979) (White, J., dissenting); San Antonio Indep. Sch. Dist. v. Rodriguez, 411 U.S. 1, 63-70 (1973) (White, J., dissenting).

134. 381 U.S. 479 (1965).

135. Id. at $480-86$.

136. Id. at 486-99 (Goldberg, J., concurring).

137. Id. at 499-502 (Harlan, J., concurring).

138. Id. at $507-27$.

139. Id. at 527-31 (Stewart, J., dissenting).

140. Id. at 502-07.

141. Id. at 502 . 
of justification" for the interference. ${ }^{142}$ Although White referred to the strict scrutiny test, his analysis seems more like an application of a slightly invigorated rational basis test: "But such statutes, if reasonably necessary for the effectuation of a legitimate and substantial state interest, and not arbitrary or capricious in application, are not invalid under the Due Process Clause."143

The Connecticut statute failed to meet that standard. The goal of the law was said to be the prevention of promiscuous or illicit sexual relationships, a goal that White saw as "permissible and legitimate."144 But the means chosen - a ban on married couples' use of contraceptives-did not "in any way reinforce[] the State's ban on illicit sexual relationships." 145 White saw no significant relationship between the prevention of illicit sex and the state's imposition on married couples. ${ }^{146}$ Typical of that discussion is the following observation:

Perhaps the theory is that the flat ban on use prevents married people from possessing contraceptives and without the ready availability of such devices for use in the marital relationship, there will be no or less temptation to use them in extramarital ones. This reasoning rests on the premise that married people will comply with the ban in regard to their marital relationship, notwithstanding total nonenforcement in this context and apparent nonenforcibility, but will not comply with criminal statutes prohibiting extramarital affairs and the anti-use statute in respect to illicit sexual relationships, a premise whose validity has not been demonstrated and whose intrinsic validity is not very evident. ${ }^{147}$

In short, the statute did not provide a rational method for advancing the state's legitimate goals. This conclusion did not require a novel theory of penumbras and invisible emanations; it did not require a resolution of the debate between Justices Goldberg and Black regarding the scope of the Ninth Amendment; and it did not require an elaboration of the concept of ordered liberty. For White, it was enough to recognize that the marital relationship was part of the liberty protected by the Due Process Clause and that the state had regulated that relationship without sufficient justification. ${ }^{148}$

There is something attractive in Justice White's seemingly simple solution to the question presented in Griswold. If Connecticut's ban on contraceptives

142. Id. at 502-03.

143. Id. at 504.

144. Id, at 505 .

145. Id.

146. Id. at 505-07.

147. Id.

148. White applied this same type of rationality analysis in Eisenstadt v. Baird, 405 U.S. 438 (1972), a case in which the Court struck down a Massachusetts law that permitted only married persons to obtain contraceptives, and then only with a physician's approval. Id. at 460-65 (White, J., concurring). 
was demonstrably irrational, there was no need to resolve the more complicated constitutional issues debated in the various concurrences and dissents. Yet an undue reliance on ends/means rationality can operate as an analytical trap. Specifically, rationality review may seriously undervalue the principles in conflict and lead subsequent decisionmakers to assume that the necessary is also the sufficient. For example, in Griswold had the state rationally explained its complete ban on the use of contraceptives, under ends/means rationality the requisite judicial scrutiny would have run its course. It does not necessarily follow, however, that a state should be free to regulate private conduct based upon nothing more than a standard of rationality. Any imposition of state authority to regulate private moral choice raises issues that go to the very heart of the concepts of limited government and liberal democracy. If one premise of such a political system is that the government may regulate private conduct only under narrow, specified circumstances, then something more than ends/means rationality is required to justify a law that intrudes upon the private sphere. It may well be that the Ninth Amendment was meant to embody this supposition of liberal democracy, a supposition that necessarily rejects rationality as a sufficient basis for law. Moreover, despite doctrines of judicial restraint, Griswold provided an opportunity for the Court to sort through, at least as a preliminary matter, these challenging constitutional issues. White's opinion, however, provides only minimal guidance for future applications.

The tension between rationality and the imposition of moral choice is further exposed in Roe v. Wade. ${ }^{149}$ That Justice White dissented in Roe is well known. In six spare paragraphs, his terse opinion attacked the moral and constitutional foundations of the majority opinion. ${ }^{150}$ From White's perspective, the Court elevated convenience over human life; it exercised raw power in an improvident and extravagant fashion; and, more generally, it failed to proceed in a reasonable fashion and in a manner consistent with constitutional structure. ${ }^{151}$ For Justice White, the sweeping decision in Roe - the seeds of which were barely discernible in Griswold - presents a stark and injudicious confrontation with his belief in the integral importance of careful, reasoned judgment. In his words,

I find nothing in the language or history of the Constitution to support the Court's judgment. The Court simply fashions and announces a new constitutional right for pregnant mothers and, with scarcely any reason or authority for its action, invests that right with sufficient substance to override most existing state abortion statutes. The upshot is that the people and the legislatures of the 50 States are

149. 410 U.S. 113 (1973).

150. Id. at 221-23 (White, J., dissenting).

151. Id. 
constitutionally disentitled to weigh the relative importance of the continued existence and development of the fetus, on the one hand, against a spectrum of possible impacts on the mother, on the other hand. As an exercise of raw judicial power, the Court perhaps has authority to do what it does today; but in my view its judgment is an improvident and extravagant exercise of the power of judicial review that the Constitution extends to this Court. ${ }^{152}$

Justice White never acquiesced in the Court's jurisprudence of abortion, ${ }^{153}$ and in a dissenting opinion in Thornburgh v. American College of Obstetricians and Gynecologists ${ }^{154}$ he called upon the Court to overrule Roe. In Thornburgh, he explained that although he had no doubt that a woman's ability to choose an abortion came within the liberty protected by the Due Process Clause, he did not agree that this liberty interest was fundamental enough to be entitled to anything more than the scrutiny provided by the rational basis test.

Fundamental liberties and interests are most clearly present when the Constitution provides specific textual recognition of their existence and importance. Thus, the Court is on relatively firm ground when it deems certain of the liberties set forth in the Bill of Rights to be fundamental and therefore finds them incorporated in the Fourteenth Amendment's guarantee that no State may deprive any person of liberty without due process of law. When the Court ventures further and defines as "fundamental" liberties that are nowhere mentioned in the Constitution (or that are present only in the so-called "penumbras" of specifically enumerated rights), it must, of necessity, act with more caution, lest it open itself to the accusation that, in the name of identifying constitutional principles to which the people have consented in framing their Constitution, the Court has done nothing more than impose its own controversial choices of value upon the people. ${ }^{155}$

White then described two approaches that have informed the judicial search for nontextual fundamental rights: rights "implicit in the concept of ordered liberty" and rights that are "deeply rooted in this Nation's history and tradition." 156 Neither test provides a mechanical yardstick; rather, "[t]heir utility lies in their effort to identify some source of constitutional value that reflects not the philosophical predilections of individual judges, but basic choices made by the people themselves in constituting their system of

152. Id. at 222.

153. Harris v. McRae, 448 U.S. 297, 327-29 (1980) (White, J., concurring); Bellotti v. Baird, 443 U.S. 622, 656-57 (1979) (White, J., dissenting); Planned Parenthood v. Danforth, 428 U.S. 52, 92-101 (1976) (White, J., concurring and dissenting).

154. 476 U.S. 747 (1986).

155. Id. at 790 .

156. Id. at $790-91$. 
government ...."157 White also recognized the role of precedent in providing a foundation for the discovery and expansion of such rights. He then ended this section of the opinion with an explanation of why abortion rights are neither implicit in the concept of ordered liberty, deeply rooted in our history or tradition, nor supported by precedent.

Given the nonfundamental nature of abortion rights, the regulation of abortion, according to White, should be left largely to the states.

Abortion is a hotly contested moral and political issue. Such issues, in our society, are to be resolved by the will of the people, either as expressed through legislation or through the general principles they have already incorporated into the Constitution they have adopted. Roe v. Wade implies that the people have already resolved the debate by weaving into the Constitution the values and principles that answer the issue. As I have argued, I believe it is clear that the people have never ... done any such thing. I would return the issue to the people by overruling Roe $v$. Wade. ${ }^{158}$

Curiously, White's blunt dissent in Roe is both more powerful and more sophisticated than his more elaborate and seemingly more polished dissent in Thornburgh. For example, the assertion that the democratic will of the people ought to resolve moral issues begs important questions about individual moral choice and the role of government in coercing particular "moral" choices. That aside, his overt reliance on doctrine seems so unsatisfying and so uncharacteristic. In Roe, White explicitly confronted what he perceived to be the moral and philosophical issues presented by the plaintiff's challenge to the Texas abortion statute. The question was not whether through doctrinal passageways one could discover a fundamental right; rather, the question was whether the circumstances provided an adequate basis for state intervention in the realm of private choice. If White was correct in thinking that Roe's argument favored the convenience of the mother over the life of an unborn child, he could have made a powerful argument that the state would have a strong interest in protecting the life of that child, just as the state has an interest in preventing violence to any member of the community.

In other words, the Roe dissent focused on the critical issues. The Thornburgh dissent, on the other hand, adopted a fairly standard doctrinal approach that drew an analytical line between structure and liberty and assumed that resolution of the controversy actually turned on whether a woman's right to privacy could be fairly characterized as fundamental. As such, the Thornburgh dissent seems to be more a reflection of the highly structured, doctrinal style of the Roe opinion (and subsequent abortion

157. Id. at 791 .

158. Id. at 796-97 (footnote omitted). 
jurisprudence) than a realistic appraisal of the issues at stake. Such an appraisal would not necessarily lead to the affirmation of abortion regulations, but it might lead to a better understanding of the interests involved in the controversy. It would at least point to the right question: under what circumstances, if any, should the state, rather than the mother, make decisions about childbirth. Of course, from a classic liberal perspective, the presumption is in favor of individual over collective choice.

The same tension between collective and individual choice came to the fore in Bowers v. Hardwick, ${ }^{159}$ a case in which the Court affirmed a state's right to criminalize acts of homosexual sodomy. Writing for the majority, White stated the issue directly: "The issue presented is whether the Federal Constitution confers a fundamental right upon homosexuals to engage in sodomy and hence invalidates the laws of the many States that still make such conduct illegal and have done so for a very long time."160 From the outset the facts are critical: both the specific facts of the controversy-homosexual sodomy - and the broader, historical facts involving the traditional regulation of such conduct. Justice Blackmun, in dissent, saw the issue in more conceptual terms: "[T]his case is about 'the most comprehensive of rights and the right most valued by civilized men,' namely, 'the right to be let alone." "161 These words appear to be no more than a platitude, but ironically, Justice Blackmun's conceptual approach may have brought him closer to the heart of the case than did Justice White's more fact-bound description.

Justice White's analysis in Bowers parallels his dissent in Thornburgh. According to White, the right to engage in sodomy was not "implicit in the concept of ordered liberty,' such that 'neither liberty nor justice would exist if [it] were sacrificed."'162 Nor was such a right "deeply rooted in this Nation's history and tradition." 163 Beyond that, White was unwilling to further develop the law of fundamental rights in this specific context. In so refusing, he referred to the "face-off" between the judiciary and "the Executive" in the 1930's "which resulted in the repudiation of much of the substantive gloss that the Court had placed on the Due Process Clauses," 164 and observed:

There should be, therefore, great resistance to expand the substantive reach of those Clauses, particularly if it requires redefining the category of rights deemed to be fundamental. Otherwise, the Judiciary necessarily takes to itself further authority to govern the country

159. 478 U.S. 186 (1986).

160. Id. at 190.

161. Id. at 199 (Blackmun, J., dissenting) (quoting Olmstead v. United States, 277 U.S. 438, 478 (1928) (Brandeis, J., dissenting)).

162. Id. at 191-92 (quoting Palko v. Connecticut, 302 U.S. 319, 325-26 (1937)).

163. Id. at 192 (quoting Moore v. East Cleveland, 431 U.S. 494, 503 (1977)).

164. Id. at 194-95. 
without express constitutional authority. The claimed right pressed on us today falls far short of overcoming this resistance. ${ }^{165}$

The contrast between White's ready acceptance of the sexual rights of married couples as fundamental in Griswold and his equally ready refusal to so categorize the sexual activities of homosexuals is evident. Of course, the traditional and historical recognition of marriage may provide an ample basis for distinguishing these categories of rights. Similarly, the historical regulation of abortions may distinguish the right to procure an abortion from other rights relating to procreation and childbirth. Yet Bowers seems to fall into the same analytical trap as the Thornburgh dissent. The question is not whether sodomy (or the right of privacy or the right to be let alone or whatever characterization you please) is a fundamental right; nor is it whether the Court should resurrect the substantive due process doctrine of the Lochner era. The question is whether the collective wisdom of the state should trump the individual's presumptive freedom of choice. Again, I am not suggesting a particular answer, only a particular question.

Even if one accepts the wisdom of judicial restraint and even if one accepts the doctrinal trouncing of Hardwick's claim, something in the Bowers opinion seems lacking. I have written elsewhere that the decision in Bowers appears to be as much a repudiation of Roe $v$. Wade as it is a denial of the rights of homosexuals. ${ }^{166} \mathrm{I}$ shall not repeat that argument at length. Suffice it to say that Justice White's opinion in Bowers assumed that the primary issue to be resolved is the fundamental rights status of homosexual sodomy. There was, however, a more basic issue - the potential irrationality of the state's law. That issue was addressed and resolved in the penultimate paragraph of Justice White's opinion.

That paragraph is a disappointment. It neither insists upon a rational justification for the law, nor investigates any other explanation of its origin. Instead, White told us the ban on homosexual sodomy is based on society's judgment that such practices are immoral. He did not explore or even describe the basis of that morality. Can a claim of immorality provide a sufficiently rational basis for a statute? This question should challenge White, who generally insisted that law be based on reason. White resolved this challenge in a single sentence: "The law, however, is constantly based on notions of morality, and if all laws representing essentially moral choices are to be invalidated under the Due Process Clause, the courts will be very busy indeed."167 Of course, all laws based on moral choice are not necessarily irrational. Just as the abstraction of morality is not synonymous with the

165. Id. at 195.

166. Allan Ides, Bowers v. Hardwick: The Enigmatic Fifth Vote and the Reasonableness of Moral Certitude, 49 WASH. \& LEE L. REV. 93 (1992).

167. 478 U.S. at 196. 
practice of reason, ${ }^{168}$ the practice of morality is not synonymous with irrationality. However, a bare claim of morality, like an abstruse legal doctrine, might be nothing more than a linguistic subterfuge to advance personal predilections or the exercise of arbitrary power. Considering the general pattern of Justice White's opinions, one would expect his Bowers opinion to have looked behind the abstract claim of morality to discover the reality behind that claim. Justice Blackmun's dissent, on the other hand, moved deftly from its conceptual opening to a discussion of the role morality plays in the imposition of legal norms. ${ }^{169}$ White's failure to offer a simple discussion is surprising in light of his penchant for realistic analysis and his sensitivity to issues of individual freedom in the context of freedom of expression and equal protection.

Ironically, Bowers represents a perfect foil for the application of the art of legal realism. The nagging absence of any discussion of rationality in Bowers presents a stark contrast with White's other decisions that looked behind the facade of the law. For if laws regulating human conduct can be justified on a mere claim of abstract morality, then such laws are truly "hocus-pocus" enshrining the public enforcement of arbitrary power.

I have puzzled over the obvious tension between White's willing endorsement of constitutional creativity in the contexts of separation of powers and desegregation and his disapproval of such creativity in the context of certain nontextual rights. Several possibilities occur to me. Whereas separation of powers involves the judicial validation of political judgment, the discovery of unenumerated rights involves a direct act of judicial creation or discovery, coupled with the invalidation of political judgment. Thus, White accepts a model of activist government, relatively uninhibited by strict rules of constitutional doctrine, regardless of whether those rules are premised upon the separation of powers or the concept of individual liberty. The demise of Lochner, to which White refers in Bowers, represents the demise of all strict limitations, and accordingly ushers in a new era for imposing collective choice in a vast array of social and economic issues.

This explanation does not, however, account for White's more activist posture in the realm of desegregation. In that context, judicial creativity-beginning with Brown - was the essential ingredient of progress, and the potential invalidation of political judgment was not an obstacle to that creativity. One could view these decisions as reflecting a process-oriented jurisprudence, in which desegregation was a tool for restructuring social institutions and thus for promoting full participation of all citizens in the political process. This view would be consistent with White's decisions in Roe and Bowers, because the rights he rejected in those cases are not usually

168. Ides, supra note 166 , at 105-07.

169. 478 U.S. at $210-13$ (Blackmun, J., dissenting). 
viewed in process-oriented terms. What this single-minded focus on political participation overlooks, however, is that our constitutional system is concerned not only with maintaining a functioning system of government, but also with preserving the value of individual choice.

One could also read the desegregation decisions as reflecting a belief that individuals should have maximum opportunity to exercise choice. Such a reading is in tension with White's opinions in Thornburgh and Bowers and in the related contexts of separation of powers and administrative law are informed by a post-Lochner jurisprudence in which governmental action is generally imbued with a presumptive validity. Of course, precisely the opposite presumption arises in the context of laws that discriminate on the basis of race. It may well be that laws that discriminate on the basis of moral choice ought to be subject to this same suspicion. The Ninth Amendment, as Justice Goldberg suggested in his Griswold concurrence, can be interpreted as a specific reflection of this more dubious attitude toward governmental regulation of private choices.

\section{CONCLUDING OBSERVATIONS AND CRITICISMS}

This Essay began, "The respondent in this case killed a 10-year-old child." ${ }^{170}$ In that case, as in so many others, the facts were of fundamental importance to Justice White. Facts were an essential component of White's jurisprudence; they defined the scope of controversies before the Court as well as the basic foundation of the law to be applied to those controversies. If one substitutes "reality" for "facts," the foundation of Justice White's jurisprudence was realism rooted in the belief that law should reflect a pragmatic appraisal of the circumstances to which the law is to be applied. His opinions were most effective when they were premised upon that foundation. However, Justice White's jurisprudence was not based solely upon pragmatism or rationality. His approach to law certainly begins with a practical, real-world orientation. And there is no doubt that he valued the principles and practice of rational discourse. His understanding of what law is and how law functions parallels some of the insights of legal realism. But these opening gambits merely set the stage for the application of more specific values, the foremost of which was his basic faith in the American system of democracy and in the people who work within that system.

White's insistence on the broad and effective enforcement of the mandate of Brown v. Board of Education reflected his positive attitude toward the American democracy and the individual's place within that democracy. If that democracy is to be realized effectively, then the social structure, particularly the educational system, must provide all members of society the opportunity

170. Brewer v. Williams, 430 U.S. 387, 429 (1977) (White, J., dissenting). 
to acquire the tools necessary for good citizenship and economic prosperity. The broad discretion granted district court judges in implementing desegregation decrees was premised not only on a rule of reason, but also on a belief that the application of such a rule would promote the underlying value of racial justice which itself is necessary for the just and effective functioning of our political system. Similar observations could be made about White's opinions on voting rights ${ }^{171}$ and gender discrimination. ${ }^{172}$ More generally, in Justice White's jurisprudence, legal realism was a tool to advance the political and economic equality necessary to his vision of a just and effective democratic system.

This underlying faith in the political system also emerges in White's opinions involving campaign financing. His realistic appraisal of the negative effects of modern financing on political campaigns focused on concerns generated by an observable breakdown in the election process, an essential element in the political system in Justice White's view. His judgment regarding the function of political campaigns colored his interpretation and application of principles of the First Amendment. The willingness to accommodate congressional determinations as to the permissible scope of contributions and expenditures is as much a product of rationality as it is a product of a specific value judgment regarding the importance of maintaining the integrity of the electoral system.

Quite obviously, Justice White did not envision the judiciary as the primary means to implement American democracy. He believed that once the legitimate opportunity to participate was established, national, state, and local political institutions should be the primary sources of policymaking. ${ }^{173}$ Two themes run together here. First, as a realist White recognized that a modern government faces a vast array of complex social policy issues. Second, as a progressive Democrat he believed that people, working in good faith through the process of democratic government, could effect positive change. The primary judicial role was to guarantee legislative and executive freedom to make rational policy judgments and to assure that the other branches adhere to constitutional principles. In this manner, White's willingness to validate innovation in the context of the separation of powers was not merely based on

171. See, e.g., City of Pleasant Grove v. United States, 479 U.S. 462 (1987); Davis v. Bandemer, 478 U.S. 109 (1986); NAACP v. Hampton County Election Comm'n, 470 U.S. 166 (1985); City of Port Arthur v. United States, 459 U.S. 159 (1982); Rogers v. Lodge, 458 U.S. 613 (1982); City of Mobile v. Bolden, 446 U.S. 55, 94-103 (1980) (White, J., dissenting); United Jewish Orgs. of Williamsburgh v. Carey, 430 U.S. 144 (1977) (plurality opinion); Beer v. United States, 425 U.S. 130, 143-45 (1976) (White, J., dissenting); City of Richmond v. United States, 422 U.S. 358 (1975).

172. See, e.g., Mississippi Univ. for Women v. Hogan, 458 U.S. 718 (1982) (White joins majority opinion applying midlevel scrutiny); Frontiero v. Richardson, 411 U.S. 677 (1973) (White joins plurality opinion calling for strict scrutiny in cases of gender discrimination).

173. In addition to cases previously discussed in the text, see Alyeska Pipeline Service Co. v. Wilderness Soc'y, 421 U.S. 240 (1975) (holding that it is province of legislature to determine scope of exceptions to American rule regarding attorneys fees). 
a judgment that the innovations were reasonable, but also on a belief that a relatively unrestrained market for such innovation was an affirmative necessity.

The belief that people working through a structure of democratic government can effect positive change also explains White's reluctance to impose judicial solutions on other governmental units. He firmly believed that absent a clear constitutional mandate to the contrary, the best solutions were achieved through the political process. Again, we see a faith in the process and in the people working through and within that process. So long as people can vote intelligently, so long as the process remains relatively open, and so long as the appropriate agency of government exercises reasoned judgment, the presumption of legitimacy ought to prevail absent a clear constitutional mandate to the contrary. Importantly, White's response to Roe v. Wade was not to suggest an alternative model that would prevent states from permitting abortions; rather, his response was to return the matter to the states for political resolution. ${ }^{174}$

There are numerous critical perspectives from which to assess Justice White's jurisprudence. A textualist would view White's opinions as both alarming and confusing. The text of the Constitution did not, in the reckoning of Justice White, provide the sole determinant of constitutionality. History, precedent, and pressing circumstances, along with the text and the vision of the Framers, all played a part in creating an evolving body of constitutional law. That is the clear message of his separation-of-powers dissents; it is no less clear in his constructions of equal protection, freedom of expression, and fundamental rights. Sometimes the text was dispositive; sometimes it was not. Even in those circumstances in which the text appeared dispositive, the critical factor was the function beneath. ${ }^{175}$ And although Justice White sometimes reached results a textualist might applaud, such as his stand against Roe $v$. Wade, the avenues through which such results were achieved were anything but pure textual exegesis. Indeed, White agreed that the text of the Constitution provided a foundation for the Roe decision; a woman's decision to choose an abortion was within the liberties protected by the Due Process Clause. White simply disagreed with the Court's application of the text, largely due to structural considerations involving his vision of the judicial function within the political system. No, White was not a textualist in any sense other than as one who perceived the text as a significant factor in the evolution of constitutional law. Similar comments could be made from the perspectives of original intent, strict construction, or interpretivism.

A critique of Justice White's jurisprudence from a doctrinal perspective is somewhat more complicated. Despite the flavor of realism that pervades

174. Thornburgh v. American College of Obstetricians and Gynecologists, 476 U.S. 747, 785-814 (1986) (White, J., dissenting).

175. See, e.g., Buckley v. Valeo, 424 U.S. 1, 267-86 (1976) (White, J., concurring and dissenting) (application of appointments clause). 
White's opinions, he was not anti-doctrine. He did not take the cynical view that doctrine is nothing more than a composite of personal predilections. Doctrine, in his view, was an essential ingredient in the common-law process, a process which he admired and practiced; consistent with that admiration, White objected strongly to the obfuscation of accepted doctrine. ${ }^{176}$ Overall, he approached doctrine as a reflection of past judicial experience and, therefore, as a guide to the resolution of present controversies. To the extent that doctrine worked to advance good policy and to comport with realistic expectations and practices, doctrine ought to be followed. In the election financing cases, for example, White relied upon the distinction between content and conduct to expose what White perceived as the false doctrinal equation of money with speech. Doctrine was not, however, a shield to protect poor policy judgments or an insurmountable obstacle to the resolution of contemporary problems. Thus in Dun \& Bradstreet, Inc. v. Greenmoss Builders, Inc., ${ }^{177}$ White called for reconsideration of the actual malice standard established in New York Times v. Sullivan ${ }^{178}$ since, in his estimation, the standard placed a "perverse" policy premium on the publication of falsehoods. ${ }^{179}$ Doctrine was, in short, a functional tool for the measurement of experience and policy, worthy of respect only insofar as it reflected realistic expectations and promoted sound policy.

The potential objections to White's willingness to bear witness to the evolution of constitutional law are self-evident. If the text represents the specific embodiment of fundamental law created by the people, then the text is sacrosanct. "No law means no law"180 and no judge should be permitted to proceed on any other assumption. So too, if doctrine represents the judicial discovery of true constitutional vision, then alterations of doctrine should only occur when the prior vision was manifestly incorrect. To the extent that the Constitution is to evolve, that evolution should occur through the process of constitutional amendment. Measured against these principles, White's jurisprudence would be characterized as misguided. Despite being constantly labelled as a judicial conservative, from a pure textualist or a formal doctrinal perspective, he was a radical.

More generally, without a firm anchor in text or formal doctrine, a jurisprudence based on realism and reason, even though applied cogently and

176. See, e.g., R.A.V. v. City of St. Paul, 112 S. Ct. 2538, 2553-55 (1992) (White, J., dissenting) (rebuking Justice Scalia's descent into doctrinal confusion).

177. 472 U.S. 749, 765-74 (1985) (White, J., concurring).

178. 376 U.S. 254 (1964).

179. 472 U.S. at 769 ("The New York Times rule thus countenances two evils: first, the stream of information about public officials and public affairs is polluted and often remains polluted by false information; and second, the reputation and professional life of the defeated plaintiff may be destroyed by falsehoods that might have been avoided with a reasonable effort to investigate the facts.").

180. Edmund Cahn, Justice Black and First Amendment "Absolutes": A Public Interview, 37 N.Y.U. L. REV. 549, 553 (1962). 
in good faith, can nonetheless lay the foundation for the slow dissolution of our constitutional system of government. Incremental adjustments to the separation-of-powers doctrine may lead to the ultimate centralization of power, although no particular step in the process trips the wire of unconstitutionality. Similarly, a careful balancing of interests in the election financing cases that legitimizes even a slight erosion of First Amendment rights may lay the groundwork for less-than-careful balancing which infringes those rights to a much greater extent. Thus despite the attractiveness of a rule of reason, one does sometimes long for something more definite, along the lines of Justice Black's admonition that no law means no law. Of course, Justice White did enforce specific constitutional limitations, but these limitations were undoubtedly informed by value judgments regarding both the scope and the continuing vitality of the constitutional norms to be enforced. In general, however, White's jurisprudence reflected something akin to a constitutional Darwinism, permitting and validating constitutional change as a necessary part of the inevitable evolution of our social and political system.

A specific case in point is White's response to the administrative state. Not only has the administrative state transformed the tripartite model of separation of powers into a form that includes systems of centralized power that conflate legislative, executive, and judicial functions; it has placed that power in a body of supposed experts operating for the benefit of society and relatively isolated from political accountability. The Supreme Court, with Justice White's enthusiastic support, has validated this modern model of government. But, as some commentators have suggested, the validation may be somewhat premature. ${ }^{181}$ It is not entirely clear that our body of experts operates in the neutral and effective fashion that certain legal theorists predicted. Nor is it clear that highly centralized bureaucracies function in a manner that is consistent with the best interests of society. Perhaps the time has come for a new, fact-intensive, and realistic examination of the administrative state.

These and other potential criticisms bring us back to the basic premise of Justice White's political and judicial philosophy. In the end, our system of government depends on the good faith and intelligence of those who live under it and work within it. Just as the judiciary must defer to the reasonable judgment of the political branches on the assumption that those branches have acted intelligently and in good faith, the public must retain its faith in the operation of the judiciary, not as a bastion of textual or doctrinal formality, but as a reasonable arbiter of a system of government designed to adapt to changing circumstances. It was, therefore, for White's generation of jurists to permit the creation of the administrative state; it is perhaps for the present generation to question the continuing validity of that experiment.

181. E.g., Sunstein, supra note 50, at 446-52. 
A final approach to evaluating Justice White's jurisprudence might be the one suggested at the beginning of this Essay; namely, to forgo doctrinal labels and to examine White's opinions on their own terms. If I am correct that Justice White was a practitioner of modified legal realism, who possessed a faith in our democratic system and activist government, then the question is whether his opinions reflect an intelligent and coherent application of that combination of realism and faith. I think they do. 
